\title{
MÚSICA Y DEVOCIÓN EN GRANADA (SIGLOS XVI-XVIII): FUNCIONAMIENTO «EXTRAVAGANTE» Y TIPOLOGÍA DE PLAZAS NO ASALARIADAS EN LAS CAPILLAS MUSICALES ECLESIÁSTICAS DE LA CIUDAD ${ }^{1}$
}

\author{
Juan RUIZ JIMÉNEZ
}

\begin{abstract}
Granada was unusual in that it possessed three stable musical chapels that served the three most important religious institutions of the city: the Cathedral, the Capilla Real and the Collegiate Church of El Salvador. Significant earnings accrued from their participation in the principal local religious feasts, as well as from their appearances at various localities within the dioceses, and beyond it, was to favour the survival of these three musical chapels. These outside performances constitute the most important connecting point between the music developed inside the temples and its projection to diverse religious and secular settings within the urban environment.

The structure of the city's three musical chapels included, besides the customary structure common to the rest of Spain, three job categories classified according to earnings. The main characteristic being that none of these positions included a fixed salary from their institutions. Their study enlightens our knowledge of musical training as well as of the qualitative and quantitative changes and development in the Granadine musical chapels, especially from late 17 th century until well into the 19th century.
\end{abstract}

\section{Resumen}

Granada presenta la peculiaridad de contar con tres capilias musicales estables al servicio de las tres instituciones religiosas más importantes de la ciudad: la catedral, la Capilla Real y la colegiata del Salvador. Éstas obtendrán importantes ingresos procedentes de su participación en las principales fiestas religiosas locales, así como de sus actuaciones en numerosas poblaciones de la diócesis, e incluso fuera de ella, que propiciarán su supervivencia. Los desplazamientos al exterior constituirán el punto de conexión más importante entre la música desarrollada en el interior de sus templos y su proyección a los diversos espacios religiosos y seculares del marco urbano.

La estructura de estas tres capillas musicales incluye, además de las tipologías habituales en el resto de la geografía española, tres categorías de «plazas» que podemos clasificar según los ingresos derivados de las mismas. Su característica principal será la no percepción de rentas fijas por parte de la fábrica de sus instituciones. El interés del estudio de estas plazas radica en su vertiente formativa y modificadora de las composiciones cualitativas y cuantitativas de las plantillas de las capillas musicales granadinas, especialmente desde finales del siglo XVII hasta bien entrado el siglo XIX.

1. Un estudio preliminar, con el título «Las plazas no asalariadas en las capillas eclesiásticas de Granada», fue leído en el Seminario «La catedral como institución musical (1500-1800)» (Ávila, 10-12 mayo de 1996). Un extracto de este artículo, bajo el título «The Interior-Exterior Duality in the performances of the musical chapels of Granada: Non-salaried posts and "extravagantes performances"», fue presentado en el 16th International Congress «Musicology and Sister Disciplines: Past, Present and Future», organizado por la International Musicological Society (Londres, 14-20 de agosto de 1997). 
Tradicionalmente, la mayor parte de los múltiples estudios realizados sobre las capillas musicales religiosas se han ocupado de los grandes centros catedralicios españoles, dejando de lado las capillas asentadas en centros de menor poder económico como colegiatas y parroquiales. Del mismo modo, estos estudios han contemplado parcialmente las actividades musicales por ellas desarrolladas, focalizándose en las desplegadas en el interior de sus recintos patrocinadores. Sólo de forma anecdótica, se hace alusión a sus desplazamientos al exterior, con lo que se ha obviado la parcela que constituía una de las principales preocupaciones y fuente de ingresos para los integrantes de estas capillas. El estudio de esta faceta, presente, en mayor o menor medida, en todos los núcleos urbanos con sedes episcopales o colegiales de importancia, pone de manifiesto una actividad musical que si bien está centrada o polarizada en sus principales centros eclesiásticos, irradia también a partir de ellos y se disemina en el entramado de los diferentes espacios religiosos de la ciudad.

Frente a las visiones más o menos estáticas dadas de las capillas musicales eclesiásticas, veremos en este trabajo como estas actuaciones condicionaban su número, estructuras y los repertorios interpretados, favorecían los intercambios musicales, generaban conflictos de intereses entre patrones y patrocinados, etc. Nos encontramos, pues, frente a agrupaciones tremendamente dinámicas, que siempre tratarán de adaptarse de la mejor manera posible para obtener el máximo rendimiento económico.

Granada presenta la peculiaridad de contar con tres capillas musicales estables al servicio de las tres instituciones religiosas más importantes de la ciudad: la catedral, la Capilla Real y la colegiata del Salvador. A ellas, hay que sumar las capillas establecidas en diferentes conventos, entre las que, sin duda, cabe destacar la situada en el monasterio de San Jerónimo, que mantendrá una periódica interrelación, en mayor o menor grado, con las demás ${ }^{2}$. Al lado de estas capillas y en competencia con ellas, encontraremos pequeñas agrupaciones, de vida más o menos efímera, que participarán en las actividades musicales desarrolladas en la geografía urbana granadina.

La ciudad contará, ya en 1613, con 4 iglesias capitulares, 24 parroquiales (dos de ellas anejas a capitulares) y 30 conventos, que se elevarán a 38 a mediados del siglo XVII ${ }^{3}$. Al igual que en el resto de España, las fiestas, con una fuerte ambivalencia religioso-profana, constituyen para sus ciudadanos las principales ocasiones de oír música, junto a las misas y oficios religiosos. El enorme desarrollo que éstas adquirieron durante el Barroco, instrumentalizadas por el poder, ya que lo acredita y sirve para desviar la atención del pueblo en tiempos de dificultades, generaron un mercado musical que propiciará la superviviencia de estas tres capillas musicales. Sus integrantes obtendrán importantes ingresos procedentes de las actuaciones realizadas en los centros eclesiásticos durante las festividades de mayor relevancia, así como de sus desplazamientos a diferentes localidades de la diócesis, e incluso fuera de ella.

2. Ruiz Jiménez, Juan: La colegiata del Salvador en el contexto musical de Granada, Tesis Doctoral inédita, Universidad de Granada, 1995, p. 360-362.

3. La ubicación de estos centros religiosos puede verse en el grabado de Francisco de Heylan de la plataforma de la ciudad de Granada, realizada por Ambrosio de Vico en 1613, y en el mapa topográfico de la misma ejecutado por Francisco Dalmau en 1796. 
En la primera parte de este artículo, nos centraremos en estos desplazamientos, en lo que hemos denominado en nuestra tesis doctoral funcionamento extravagante de las capillas. En la segunda, analizaremos su relación directa con la existencia y financiación de las plazas no asalariadas presentes en las mismas.

El término «extravagante», con el que se denominará a una peculiar capilla musical granadina que durante gran parte de su existencia estuvo vinculada a la colegiata del Salvador, se aplicaba, según el Diccionario de Autoridades: a aquel «que no es del número, ni tiene asiento fixo, ni está computado ni incluido ni incorporado con alguna compañía, comunidad o clase de personas o estados, sino que libremente obra y exerce por sí y donde quiere su oficio o cargo». Precisamente, esta será la cualidad que caracteriza a «los Extravagantes», la no dependencia económica de una institución religiosa ${ }^{4}$. Por derivación, este vocablo se aplicará al servicio de fiestas en el exterior de los recintos eclesiásticos, tanto dentro como fuera de la ciudad. Así, el cabildo de la Capilla Real, en 1644, prohibirá a los músicos de su capilla que vayan «a fiestas Extravagantes por el desdoro y mal parecer». En 1707, recriminará a los músicos porque en sus salidas dejaban los peores en la Capilla Real, y señalará: «quan injurioso es a la autoridad de esta Real Capilla que sus músicos acuden a los lugares sirviendo fiestas, acción que sólo compete a los Extravagantes y de que toman la denominación» ${ }^{5}$. Vemos una doble vertiente en lo peyorativo con que se trata el término: de un lado, debido al desamparo, a nivel musical, y la correspondiente falta de ostentación en que podía quedar el servicio en su templo; de otro, mucho más importante, el hecho de la carga simbólica que la capilla de música tiene del decoro de la institución, como representación adecuada de ella en el exterior. Por este último motivo, serán los propios cabildos los que favorezcan e incluso obliguen a estas salidas a su capilla cuando les interese mostrar su grandiosidad, generosidad y fasto. En este sentido, los músicos prebendados (racioneros, en la catedral; capellanes reales en la Capilla Real) sólo participarán excepcionalmente en estos desplazamientos ${ }^{6}$. Encontramos también el término «capilla de músicos extravagantes» en la ciudad de Antequera, para referirse a la nueva capilla de músicos que ubicó su sede en la iglesia de S. Pedro de esta ciudad, en torno a $1646^{7}$.

4. El estudio de esta capilla musical fue abordado en nuestra tesis doctoral. Véase RuIz JimÉnEZ, J.: La colegiata del Salvador..., p. 47-52.

5. Actas capitulares de la Capilla Real de Granada (AC.CR.), t. 5, fol. 155v; t. 11, fol. 382r. Archivo de la Capilla Real de Granada.

6. A modo de ejemplo, el cronista de las fiestas realizadas para celebrar la beatificación de Pedro de Arbués (1664), patrocinadas por el Tribunal de la Santa Inquisición, recogerá lo excepcional del hecho: se canto el Te Deum laudamos «que con grande solemnidad e instrumentos prosiguió la capilla de música de la yglesia mayor desta ciudad, gouernada por su maestro y demás racioneros músicos, los quales aunque no salen a otros actos fuera de su yglesia quisieron asistir a esta solemnidad, lleuados de la devoción al santo». A-31-130 (25), Biblioteca General de la Universidad de Granada. No debía ser excepcional que los músicos asistieran, en determinadas ocasiones, a ciertas festividades, de forma gratuita, movidos por su propia religiosidad. Así, en las Constituciones de la Hermandad de la Esclavitud del Santísimo Sacramento (1781), sita en la parroquial de Santa María Magdalena, se solicita una Bula para obtener indulgencias a los que contribuyeren al culto del Santísimo Sacramento. Entre ellos, encontramos a aquellos que «con su trabaxo personal (como suzede con los músicos que por deboción y sin estiendio alguno asisten quando sale su Magestad a tocar sus ynstrumentos desde que tubo principio esta deboción hasta de presente) contribuyen a la mayor dezencia y solemnidad de estos cultos». López MuÑoz, Miguel Luis: Las cofradias de Santa María Magdalena de Granada en los siglos XVII-XVIII, Granada, Universidad, 1992, p. 292.

7. Llordén, Andrés: «Notas históricas de los maestros de capilla en la Colegiata de Antequera», Anuario Musical, XXXI-XXXII, 1976-1977, p. 139-140. 
El núcleo original de formación de la capilla musical de los Extravagantes pudo estar en alguna de las agrupaciones musicales independientes que desde el siglo XvI habían funcionado en la ciudad, con una vida más o menos fugaz. Cronológicamente, éstas enlazan con la tradición andalusí de las zambras, que desde el arzobipado de Hernando de Talavera acompañaban ocasionalmente al Santísimo Sacramento en las procesiones del Corpus Christi ${ }^{8}$. Grupos de ministriles como los de Sarabia (1543) o Juan de Oñate (1560) tenían también un funcionamiento autónomo $^{9}$. En 1599, se constituirá una compañía de ministriles «para vsar el dicho arte en esta ciudad en las fiestas y ocasiones que se ofreçieren, por tiempo de seys años». Esta agrupación se establece entre Alonso Romero, ministril, y Marcos Lumbreras, Bartolomé de Salazar y Diego de Lara, todos igualmente ministriles. Las condiciones del contrato son de gran interés para conocer el funcionamiento de estas capillas «extravagantes».

- En primer lug:r, debían actuar unidos en qualquier «fiesta e procesión» para la que fueran llamados y se hubieran concertado previamente.

- Cualquiera de ellos podría contratar una fiesta, intentando obtener los mejores honorarios posibles.

- Debían recibir los emolumentos resultantes estando juntos, y realizar cuatro partes que repartirían entre ellos por igual. Si alguno cobraba la fiesta por su cuenta, sería penalizado.

- No podría ninguno de los integrantes de la compañía servir fiestas sin sus compañeros, ni podría asistir con otra compañía de músicos. Si lo hiciera, estaría obligado a darles el doble de la cantidad que él hubiera ganado, y esta se repartiría entre los tres restantes.

- Durante los dichos seis años, ninguno se excusaría para faltar a las fiestas, «sino fuere que fuere ganando fuera de Granada, o en ella, algún salario de yglesia e monasterio», o por establecerse fuera de la ciudad.

- Si alguno de ellos se fuese a vivir a otra ciudad, "ya sea con salario de yglesia o no», los otros compañeros tendrían la obligación de aguardarle durante cuatro meses. Si regresaba en este período, deberían admitirle, pero pasado este tiempo quedaría despedido y no podría ser readmitido sin la voluntad de los otros tres compañeros ${ }^{10}$.

En 1616, se formará una «aparzería» entre Juan de Cienfuegos, «maestro de ynstrumentos, harpa y bielas», y Juan Bautista, «texedor de arte de la seda», Juan de Soto, «zapatero» y Pedro Rodríguez de Soto, «que de presente está sin vista». Establecen el contrato para «tañer y

8. Sobre la pervivencia de las zambras en el siglo xvi, véase Ramos López, Pilar: La música en la Catedral de Granada en la primera mitad del siglo XVII: Diego de Pontac, vol. I, Granada, Diputación y Centro de Documentación Musical de Andalucía, p. 49-54. Hemos podido constatar que, en 1530, existía un grupo organizado de «zambreros» constituido por 11 moriscos. A la muerte de su «mayoral», el famoso Fernando Morales «el fisteli», solicitaron a la Cámara de Castilla el nombramiento de un nuevo encargado. Las funciones que servían eran: «procesiones e reçibimientos de trazadas [sic] quando vienen a esta çibdad, e otras fiestas e alegrías e zanbras que en esta çibdad se acostumbran a azer e hazen». Proponían para el cargo a Sebastián de Palacios. Ruiz Jiménez, J.: La colegiata del Salvador..., p. 355-356.

9. Para evitar lo prolijo de las citas documentales, remitiremos, con frecuencia, a nuestra tesis doctoral, donde estas se encuentran anotadas de forma pormenorizada. Ruiz JiménEZ, J.: La colegiata del Salvador..., p. 356-357.

10. Hemos podido localizar algunos datos interesantes de los integrantes de esta compañía de ministriles: Diego de Lara era «maestro de tañer y danzar» (1598). Bartolomé de Salazar era también tejedor de sedas, había sido ministril de la Capilla Real (1598). Marcos Lumbreras era, además de ministril, tejedor de terciopelo (1597). Ruiz Jiménez, J.: La colegiata del Salvador..., p. 357-358. 
cantar» juntos por tiempo de un año. Las condiciones del contrato se resumen en los siguientes puntos:

- En primer lugar, Juan de Cienfuegos «a de hazer como maestro de tañer con los ynstrumentos que fuere menester, y enseñar y dar las bozes a todos los conpañeros contenydos en esta escriptura». Además, debería ensayar con ellos diariamente, así como buscar y contratar todas las fiestas posibles y avisarles de ellas para que asistiesen a «cantar y tañer» todos juntos.

- En segundo lugar, se señala: que «an de tañer y cantar biuelas i harpa e con lo que fuere nezesario que supieren tocar». Estarían obligados a asistir a todos los ensayos para aprender las composiciones, así como «a tañer y cantar» en todas las funciones concertadas por Juan de Cienfuegos en los lugares y por los precios por él estipulados.

- Por último, los gajes obtenidos se repartirían en la siguiente forma: se harían partes de 25 reales (850 maravedís), de las cuales una de ellas correspondería a Juan de Cienfuegos, que actuaba como maestro. El resto del dinero se distribuiría en partes iguales entre los cuatro ${ }^{11}$.

Vemos, por lo tanto, que los miembros de estas agrupaciones podían estar vinculados o promocionar a las propias capillas eclesiásticas estables, así como estar sometidos a un pluriempleo, necesario para su sustento. Según la propia redacción de los documentos, nos encontramos frente a asociaciones de músicos para el servicio de festividades tanto eclesiásticas como civiles ${ }^{12}$. Este núcleo presentaría, casi con toda seguridad, las mismas características que los grupos de ministriles citados anteriormente y de aquellos que fueron escriturados por la catedral (1561) y la Capilla Real (1562) que tendrían un funcionamiento autónomo con anterioridad a estos contratos ${ }^{13}$.

En los Anales de Granada, redactados en la primera mitad del siglo xvII por Francisco Henríquez de Jorquera, se recogen citas a numerosas fiestas que se celebraban en iglesias, conventos, e imágenes de la ciudad. De ellas, entresacamos la efectuada en el Colegio de San Pablo de la Compañía de Jesús, a cuya iglesia se trasladará en el siglo xviII la colegiata del Salvador. Señala Henríquez de Jorquera, que en esta institución jesuítica radicaban cuatro hermandades, entre ellas, la Hermandad del Espíritu Santo, servida por los mercaderes, «y jente ciudadana rica», que además de celebrar la festividad del Espíritu Santo con una grandiosa fiesta durante tres días, «celebran los tres días de carnestolendas por mañana y tarde, manifestando el Santísimo Sacramento con grandes músicas y grandes oradores y mucho gasto de cera» ${ }^{14}$. Hemos localizado el contrato para la celebración de esta festividad, correspondiente al año 1625, el cual nos proporciona noticias de otra agrupación musical. El contratante era el mercader Pedro González

11. Ruiz Jiménez, J.: La colegiata del Salvador..., p. 358.

12. Recientemente se ha publicado un interesante documento que describe minuciosamente la regulación y actividades de una compañía de ministriles que funcionó en Toledo de 1668 a 1677 . Ésta presenta numerosos puntos en común tanto con las compañías autónomas de Granada, como con el funcionamiento de las capillas musicales estables en sus desplazamientos al exterior. Véase MARTínez Gil, Carlos: «Ofrécese compañía de ministriles para tocar fiestas (sobre la formación de una compañía de ministriles en Toledo en 1668)», Revista de Musicología, XIX, 1996, p. 105-132.

13. Ruiz JiménEZ, J.: La colegiata del Salvador..., p. 323.

14. Henríquez de Jorquera, Francisco: Anales de Granada, Edición de Antonio Marín Ocete, Granada, Universidad, 1987 , p. 233-234. 
de Yxavedra, el grupo contratado estaba formado por Juan Fernández, «autor de música», que junto a «otros quatro conpañeros que son zinco, los dos con harpas dos con dos biguelas y el otro con biguela de arco, yvan a serbir con tres bozes en la fiesta que se a de hazer las carnestolendas deste dicho presente año en el nombre de Ihesus desta dicha zibdad. Tres días que son domyngo todo el día tarde y mañana, y lunes todo el día, y martes todo el día, y a su contento y satisfazión está por razón que se le a de pagar y satisfazer por el travaxo que an de poner zien reales». Es sobre todo de gran interés la composición de este conjunto (al igual que la compañía citada de Juan de Cienguegos), con arpas, vihuelas y vihuela de arco, instrumentos para la realización del continuo, los cuales no se habían incorporado, en esas fechas, en el repertorio que las capillas musicales estables de la ciudad interpretaban en sus recintos eclesiásticos. Creemos que esto tiene que ver tanto con el tipo de festividad celebrada, como con el hecho de una mayor libertad de acción, en los instrumentos utilizados y en el repertorio, fuera de las restricciones y estricto control de sus respectivos cabildos ${ }^{15}$. Son frecuentes las recriminaciones que los cabildos hacen a sus músicos por su comportamiento «indecoroso» en estas salidas al exterior, que no se limitan a condenar las distracciones con juegos de naipes o las disputas surgidas entre ellos. Ligeramente fuera de nuestros límites cronológicos, traemos a colación la reprimenda dada al maestro de capilla de la catedral, Vicente Palacios, en 1817, por parte del cabildo, la cual confirma nuestra hipótesis. El cabildo de esta institución recibirá una queja «de algunas personas piadosas e instruidas», debido a que la capilla había tocado sinfonías, motetes y arias en el convento de Santo Domingo, «en que no se vio aquella religiosidad, decencia y magestad que se previene por los padres de la yglesia y derecho canónico en la música de los templos». Además, como si se tratase de «una orquesta de teatro», el maestro de capilla Vicente Palacios, que había asistido sin licencia del cabildo, salió a dirigir a los músicos y «en su manejo se hacían notables por los fieles ciertas maneras ruidosas de aplauso o de corrección, hechas con tanto ruido que distrahían la atención de todos». En 1815, el cabildo de la catedral manifiesta la introducción en el repertorio de algunas obras «que no son de la magestad y santidad del templo», por lo que acordó que los prebendados organista y maestro de capilla censuraran todas aquellas obras que tuvieran algo «que parezca teatral». Asimismo, se ordenó recoger todas aquellas obras profanas «para impedir de este modo la contingencia de que se puedan cantar por la capilla» ${ }^{16}$.

Las primeras noticias de la capilla musical de los Extravagantes datan de 1607. Este año, Francisco Vázquez, ministril de la Capilla Real, había ido a tañer con «los menestriles estrauagantes», motivo por el cual sus compañeros no querían pagarle una parte del dinero ganado por ellos en otra actuación. El cabildo de la Capilla Real le prohibirá, de manera tajante, ir a tocar

15. Con anterioridad a estas fechas, sólo en una ocasión aparecen documentadas las vihuelas y el arpa acompañando los villancicos de Navidad, en 1604, en la Capilla Real. Sabemos que los ministriles de la catedral y Capilla Real eran diestros tañedores de instrumentos diferentes a los que tocaban en estas instituciones. En el caso de la catedral, en 1595, sus ministriles usaban vihuelas, vihuelas de arco, guitarras, rabeles y arpas para su propio recreo. Este hecho queda confirmado también por el ministril de la Capilla Real Juan Romero. En 1575, establecerá un contrato con Ana María, hija del mercader Juan de Medina, para enseñarle a tocar el harpa. Ruiz Jiménez, J.: La colegiata del Salvador..., p. 209, 263, 359. RuIZ JiméNEZ, J.: «La música en Granada en la segunda mitad del siglo XVI». Conferencia dada en el XXVII Curso Manuel de Falla.

16. Ruiz Jiménez, J.: La colegiata del Salvador..., p. 375. 
con «los estrauagantes». Los años 1627-1629, «los cantores i ministriles estrabagantes», servirán la festividad de la titular de la parroquial de Santa Ana. En 1630, son recibidos, por primera vez, en la colegiata del Salvador como su capilla de música, lo que les permitía utilizar el nombre de esta institución ${ }^{17}$.

Desde el siglo XVI, las capillas musicales de la catedral, Capilla Real y colegiata del Salvador, entrarán en competencia con estas agrupaciones independientes por el servicio de las festividades desarrolladas en el tejido urbano formado por los centros religiosos de la ciudad. Las primeras se veían favorecidas del prestigio que gozaban las entidades que las patrocinaban, pero también fuertemente condicionadas por las restricciones dictadas por sus cabildos rectores. Las prohibiciones sistemáticas y periódicas de estas salidas, sin la licencia pertiente, surtirán poco efecto. Ésta será la causa del establecimiento de legislaciones que intentaran ejercer un control más estricto de estos desplazamientos. En la rivalidad desencadenada para acaparar el mercado, la guerra de precios que debió existir entre las distintas capillas jugará un papel destacado ${ }^{18}$.

La Capilla Real nos ofrece un detallado ejemplo de este tipo de legislaciones. Desde principios del siglo XVII, encontramos esporádicamente a algunos de sus músicos acompañando a los Extravagantes, «por no tener los músicos de la capilla fiestas muchos días». Hasta tal punto debía estar solicitada la presencia de esta capilla, que, en 1636, los cantores de la Capilla Real solicitarán que el cabildo contratase a Melchor Dardo, sacabuche de la misma, debido a que no tenían «fiesta ninguna, porque era tan mañoso e ynteligente que se las quitaua todas». Para intentar conciliar las posturas del cabildo y de los músicos de la capilla, en 1633, se establecerá una normativa que regulará las salidas de la misma al exterior. Fue realizada por una comisión del propio cabildo y por su maestro de capilla. Señala en su encabezamiento: que se mandó hacer «el arançel siguiente conforme al estilo que se tiene y guarda en las demás yglesias cathedrales». Esta reglamentación comprendía los siguientes puntos ${ }^{19}$ :

$1^{\circ}$ No podría salir la capilla de música fuera de su iglesia sin licencia del cabildo, y sólo después de haber cumplido con sus obligaciones en la Capilla Real. Esta claúsula se hacía extensiva tanto a los desplazamientos dentro de la ciudad como a los pueblos limítrofes.

$2^{\circ}$ Ningún músico podría actuar de forma aislada, excepto en aquellas fiestas que llamaran únicamente a los ministriles o a los cantores. Si estos últimos tenían necesidad de ser acompañados por un bajonista y un cornetista, les darían una parte igual a lo que cada cantor perci-

17. Ruiz Jiménez, J.: La colegiata del Salvador..., p. 47-48, 364-365.

18. Si analizamos detenidamente las cuentas de la parroquial de San Juan de Los Reyes, vemos como los Extravagantes servían las festividades por un precio menor (55-66 reales) que los músicos de la Capilla Real (77 reales). La mayor parte de los años comprendidos entre 1616 y 1684 los libramientos son de 66 reales, lo que induce a pensar que serían los Extravagantes los encargados de actuar en los festejos de San Juan Bautista a lo largo de esta etapa. Estos precios competitivos podemos verlos también en la iglesia de Santa Ana (66 reales cobrados por los Extravagantes frente a los 100 percibidos por la capilla de música de la Capilla Real). En el período comprendido entre 1700-1710, los pagos efectuados a las capillas de música de la catedral y Capilla Real por su actuaciones en la iglesia de Santiago durante las festividades del Apostol serán de 60 y 50 reales respectivamente. Libros de fábrica menor de las parroquiales de San Juan Bautista, Santa Ana y Santiago, Archivo de la Curia Eclesiástica de Granada.

19. Ruiz Jiménez, J.: La colegiata del Salvador..., p. 366-377. 
biera. Esto debería respetarse igualmente en los entierros y demás actos funerales, donde no hay ministriles, pero acuden con el bajón y «bajoncillo tiple».

$3^{\circ}$ Las fiestas serán concertadas por el que fuese el encargado del «gobierno de su capilla, pues haçe officio de maestro». Si éste no quisiere, de forma democrática, elegirán un cantor que realice esta función, «como se hase en muchas partes». Debido a que, en ocasiones, «el conçertador» no era demasiado hábil para conseguir estas fiestas, el cantor o ministril que se hallare presente podría establecer el contrato por la cantidad que ordinariamente cobraban. Se matiza que sólo lo hará en estas circunstancias, y estará obligado a dar noticia de ello al «conçertador y pagador o cobrador, que todo es vno».

$4^{\circ}$ Sólo podrá percibir los honorarios el cobrador de la capilla, que estará obligado a pagar al día siguiente en la Capilla Real. Se procedía de esta manera debido a que generalmente las fiestas finalizaban tarde, y había que realizar las cuentas para establecer el dinero que correspondía a cada uno. Sólo en el caso de que la fiesta fuese por la mañana se pagaría por la tarde. Por ocuparse de la contabilidad, el cobrador recibiría media parte. Si por cualquier motivo hubiera alguna pérdida, estas serían asumidas en partes iguales por todos, cantores y ministriles.

$5^{\circ} \mathrm{Si}$ por negligencia de uno o varios músicos se cobrase menos de lo estipulado, se le descontaría a los causantes el montante de la pérdida, bien de lo que cobrare en esa fiesta, o en otra subsiguiente.

$6^{\circ}$ Asistiendo los cuatro ministriles, «aia torre que no la aia», se les dará la tercera parte. Si alguno se ausentase, total o parcialmente, siempre que no fuera por enfermedad, se les daría sólamente la cuarta parte. En las fiestas donde no hubiese que tocar en la torre de la iglesia se le descontará a los ministriles de su tercera o cuarta parte cinco reales, que se repartirán igualitariamente entre los cantores. Si faltase algún cantor o ministril, los demás podrán invitar a otro en su lugar «siempre que sea para suplir».

$7^{\circ}$ La porción correspondiente a los cantores se repartirá con equidad entre todos. Los ministriles Juan Gutiérrez y Sebastián Gómez percibirán partes enteras similares a los cantores; José de Florencia y Juan Muñoz media parte cada uno; Pedro de Burgos (encargado de hacer el oficio de maestro) «por el cuidado del libro y papeles» cobrará un real de cada fiesta. Si sobrara alguna cantidad, «que no sea partible», será para el cobrador de la capilla.

$8^{\circ}$ Tendrán la obligación de llevar un libro de cargo y descargo, donde se registrará lo que se cobra en cada fiesta y lo que corresponde a cada uno, «como haçen en todas partes», para evitar el fraude y la sospecha. Este libro estará en poder del cobrador.

$9^{\circ}$ Habrá un contador para que haga públicas las cuentas, elegido por los músicos de la capilla. Si algún cantor estuviese «lejítimamente» enfermo, sin poder salir de casa, cobrará su parte entera. Para verificar la enfermedad se nombrarán dos visitadores que comprobarán si ésta es real o ficticia, para lo cual recabarán, en caso necesario, información del médico que lo atendiese.

$10^{\circ}$ Los cantores que sirvieran alguna fiesta fuera de Granada deberían repartir sus ganancias con los que se quedasen en la Capilla Real de la siguiente forma: descontada la tercera o cuarta parte de los ministriles, del resto se harán dos partes, una de ellas para los que se despla- 
zasen, la otra mitad entre todos. Las salidas de una sección u otra de la capilla se realizarían de forma alternativa.

$11^{\circ}$ Los ministriles tendrán la obligación de acudir con todos sus instrumentos, «así de chirimías, como de baxón y cornetas y sacabuche», como hacen en la Capilla Real «en las fiestas principales», para que la fiesta esté bien servida. Si se les rebajase en algo los honorarios por no hacerlo así, sería únicamente la pérdida de ellos y no de los cantores.

$12^{\circ}$ Pedro de Burgos, o el que hiciera el oficio de maestro de capilla, deberá ser obedecido por todos como tal maestro, «así en el cantar y tañer, como en lo demás que le tocare por raçón del dicho ofiçio».

$13^{\circ} \mathrm{El}$ cabildo nombrará quién debe desempeñar el cargo de maestro, previo informe del maestro de capilla de la Capilla Real. Señala también este capítulo, que algunas veces la fiesta se canta mal por no acudir los cantores y ministriles «a probar», por lo que se decreta que aquellos que no asistan a los ensayos serán multados con un real por cada falta.

$14^{\circ}$ Por último, se precisa que para ganar la fiesta, tanto cantores como ministriles, deberán asistir en las misas «desde el último Quirie adelante», en las vísperas «desde el primer Gloria Patri» y en los actos funerales «desde el último uerso del inuitatorio en adelante, que diçe Regem cui omnia uincent».

Pocos meses después, esta normativa fue revisada y suplementada con los siguientes capítulos:

$1^{\circ}$ En primer lugar, los ministriles, que cobraban la quinta parte, llevarán la cuarta asistiendo los cuatro. Si iban tres, sólo recibirían la dicha quinta parte ${ }^{20}$. Si se les diese a los ministriles alguna «colaçión» por los contratantes, no tendrán obligación de compartirla, a no ser que ésta sea en dinero, en cuyo caso la repartirán.

$2^{\circ}$ Entre todos los músicos nombrarán quién debe ser el cobrador. Una vez concertada la fiesta, se comunicará al resto de los músicos y se registrará en el libro correspondiente.

$3^{\circ}$ En las misas «de Nuestra Señora los sáuados, y salues, y otras demás cosas menudas que no pasen de beinte reales», el reparto se hará por partes iguales entre cantores y ministriles.

$4^{\circ}$ El cobrador será el encargado de la custodia «de el libro y papeles» para las fiestas y entierros.

Este reglamento, en esencia, se conservará durante toda la existencia de la capilla, y se corresponde en algunas de sus normas con los decretos establecidos en las otras capillas musicales de la ciudad ${ }^{21}$.

Estos desplazamientos se constituirán en una de las fuentes de conflicto más importante entre los miembros de las capillas, y de éstos con sus cabildos respectivos. El principal motivo de disputa eran los contratos que algunos de los músicos de la capilla establecían de forma particular. Esto iba en perjuicio del resto de los individuos que la componían y, sobre todo, de aquellos que estaban jubilados, a los cuales correspondía también su parte en todas las funciones que iban tres.

20. Resulta extraño, ya que según la legislación original debían cobrar la tercera parte si asistían todos y la cuarta si sólo

21. Las Constituciones de las diferentes capillas musicales eclesiásticas granadinas mantienen numerosos puntos en común con la normativa aquí descrita. Ruız JiménEZ, J.: La colegiata del Salvador..., p. 183-189. 
se sirvieran fuera. Periódica y sistemáticamente, se decreta por los cabildos, debido a su constante trasgresión, que las festividades en las que actúan fuera de sus recintos las sirvan como «capilla»y «no por particulares» ${ }^{22}$.

Como hemos visto, los «percances» obtenidos se dividían en una serie de partes iguales que se repartirían entre los músicos de la capilla. Una parte de estos ingresos se destinaba al arca de la capilla para sufragar su labor social. El «conçertador» de la capilla percibía por esta función media parte extraordinaria. No aparece en Granada el termino «festero», que se sustituye por el señalado de «concertador», o «pagador» o «cobrador» de la capilla. Al maestro de capilla de las distintas instituciones, habitualmente, le correspondía parte y media de fiestas: media parte «por razón de los papeles de música» y una parte por su asistencia personal, ocasionalmente cobrará las partes de los seises que deberá emplear en su mantenimiento.

Con frecuencia, la capilla de música se dividía para salir a sus actuaciones en una fiesta, pero, excepcionalmente, en algunos servicios especiales, se les permitía acudir de forma particu$\operatorname{lar}^{23}$. Destacan, en este sentido, sus desplazamientos a cantar las Pasiones en distintos centros religiosos, siempre que hubieran cumplido previamente con su residencia en el coro $^{24}$.

En distintas ocasiones, la competencia y las prohibiciones de salidas al exterior actuarán como reguladoras del número de capillas musicales existentes en la ciudad.

Un primer ejemplo lo constituye la nueva capilla musical, al parecer de vida efímera, que, en 1623, se vinculó al convento de San Agustín (agustinos calzados). Durante la celebración de un capítulo provincial en este convento, se congregaron «todos los padres doctos de la provincia de Andalucía, Reino de Granada y Reino de Murcia, que fueron en grande número con grandes aparatos de música que truxeron del combento de Córdoua y del combento de Seuilla [...] Determinose en dicho capítulo de que se quedase la música en este combento de Granada, aunque no duró mucho el conserbarse en él porque se les bedó el salir a las fiestas y entierros, con lo qual se fueron» ${ }^{25}$. En el siglo XVIII, encontramos otro ejemplo en la capilla musical asociada a la Universidad de Beneficiados de la ciudad, que desgajada de la capilla de la colegiata del Salvador, únicamente sobrevivirá entre 1747 y $1750^{26}$. La causa principal aducida para su creación, por

22. AC.CR., t. 10, fol. 304r; t. 16, fol. 171v; t. 17, fol. 534v. Actas capitulares de la catedral de Granada (AC.C.), t. 22, fol. $87 \mathrm{v}$; t. 23, fol. $411 \mathrm{v}$; t. 24, fol. 31v. Véase Ruiz Jiménez, J.: La colegiata del Salvador..., p. $371-372$.

23. Al menos temporalmente, como ya hemos visto en la legislación de 1633, existían ciertas excepciones a esta regla general. Estas se concretan en el caso de que los ministriles fueran contratados de forma independiente para tocar en «siestas», «vocaciones» (en la víspera de la festividad), «recibimiento» de hermandades y cofradías, «grados» (celebrados por la Universidad), etc. AC.CR., t. 12, fol. 341v; t. 17, fol. 534v. AC.C., t. 20, fol. 230v; t. 23, fol. 407v, 411v; t. 24, fol. 31v.

24. Es frecuente encontrar pagos por estas actuaciones en los libros de fábrica menor de las diferentes parroquiales o en los libros de gastos de monasterios y conventos. Véase también: AC.CR., t. 7, fol. 188v; t. 9, fol. 252r, 309v.

25. Henríquez de Jorquera, F.: Anales de Granada, p. 654.

26. En torno a estas fechas, debían seguir existiendo pequeñas agrupaciones musicales independientes, necesarias para acudir a la demanda musical de la ciudad. En 1758, un grupo formado por Juan de Quintana y un hijo suyo, «que unidos con algunos otros instrumentos juntaban un javardillo», servía las fiestas de distintos sitios. Esto suponía una competencia para la capilla de música del Salvador que se solucionó admitiéndolos en ella. Encontramos también el término «javardo», con un significado similar, en la primera mitad del siglo xix. Es utilizado también, por los músicos de la catedral de Baeza, en el siglo Xviri, para referirse despectivamente a los músicos que «de manera oficiosa, no de forma reconocida y con salarios fijos», formaban la capilla de música de la colegiata de Baeza. Ruız Jiménez, J.: La colegiata del Salvador..., p. 370. 
parte de la Universidad de Beneficiados, había sido la celebración de las vísperas, sermón y misas en las fiestas de los santos titulares de las 23 parroquias de la ciudad («basílicas») ${ }^{27}$. Las presiones del cabildo de la colegiata harán que el poder real la suprima y obligará a sus músicos a su reincorporación en su capilla de origen y al cabildo a su admisión. Una de la principales argumentaciones para la abolición de esta capilla musical fue el grave perjuicio que creaba a las demás, sobre todo a la de la colegiata del Salvador, cuyos músicos, debido a su escasa dotación, necesitaban para su sustento de estas actuaciones fuera de su recinto eclesiástico ${ }^{28}$.

En la primera mitad del siglo xviI, la obra de Francisco Henríquez de Jorquera, Anales de Granada, da cuenta de las festividades llevadas a cabo en cada una de las parroquias y conventos de la ciudad en las vísperas y día de su Santo Patrón. Igualmente, enumera las cofradías y hermandades residentes en cada una de ellas, así como las fiestas que auspiciaban. Estas cofradías y hermandades presentan la doble naturaleza de culto y asistencia. En esta promoción del «culto público», cuya principal expresión son las funciones religiosas y las procesiones, manifestaciones ambas de la religiosidad popular, es donde se concreta el importante papel de patrocinio musical desempeñado por estas corporaciones ${ }^{29}$. Resulta este último de especial interés, si tenemos en cuenta que en la primera mitad del siglo xVII, siguiendo a Jorquera, existían en la ciudad 110 cofradías y hermandades, que verán incrementado su número considerablemente en el siglo XVIII. Las actividades musicales de mayor envergadura se centran en la festividad principal dotada por cada una de estas instituciones. Igualmente, el resto de las establecidas por sus constitu-

27. Desde 1530 , los beneficiados de las distintas parroquias de la ciudad pretendieron formar «cuerpo de comunidad». En 1552, el arzobispo Pedro Guerrero les concederá sus constituciones, que serán ampliadas por el arzobispo Juan Méndez Salvatierra. Igualmente, conseguirán varias Bulas de Pio V y Sixto V por las que recibirán el nombre de «Universidad y cabildo». Será Felipe II el que dotará las funciones denominadas «basílicas» para la celebración de las fiestas de los titulares de las parroquias. Chica Benavides, Fray Antonio de la, Ave María. Mamotreto, en que van encuadernados todos los Semaneros Granadinos o Gazetillas que han salido desde el lunes 9 de abril de 1764 hasta el lunes 17 de junio de 1765, Granada, Imprenta de la Santísima Trinidad, 1765 (semana 8 de febrero de 1765).

28. Ruiz Jiménez, J.: La colegiata del Salvador..., p. 54-58. Al parecer, existen numerosos puntos en común, que sería de interés estudiar comparativamente, con el funcionamiento de las capillas musicales existentes en la ciudad de Valencia en el siglo xviII. Véase BombI, Andrea: «La música en las festividades del Palacio Real de Valencia en el siglo XVIII», Revista de Musicología. XVIII, 1995, p. 175-228.

29. Este hecho puede quedar ejemplificado en el caso de aquellas hermandades servideras en la parroquia de Santa María Magdalena, aunque resulte excepcional su número en relación a otras intituciones (entre 4 y 7 según las fechas). Miguel Luis López Muñoz pudo establecer las siguientes funciones religiosas para seis de las cofradías: cofradía de Nuestra Señora y Animas (Purificación - fiesta principal-, Asunción, Natividad de María, Inmaculada Concepción, Anunciación, San Roque, Invención de la Santa Cruz), cofradía de Nuestra Señora Candelaria (Purificación - ¿fiesta principal?-, Coronación de María, Misa todos los sábados), cofradía de la Natividad de Nuestra Señora (Natividad de María - principal-, celebración religiosa - jueves-), cofradía del Cristo de la Salud (Domingo $1^{\circ}$ de mayo - principal-, misa todos los viernes), cofradía del la Esclavitud del Santísimo (Santo Viático - fin principal-, Jubileo de las 40 horas). Expresamente, en la festividad de la Purificación de la cofradía de Nuestra Señora de la Candelaria, se celebraban vísperas y misa cantada con «acompañamiento de música de capilla». En la festividad de la Natividad de María, patrocinada por su Concordia, había función y vísperas («a de aver en la torre música, fuegos y luminarias»). Esta misma cofradía culminaba su celebración del rosario de todos los jueves con la disciplina de los cofrades, en la siguiente forma: «dirá el coro de música que estará prebenido la salbe y letanía de Nuestra Señora y acabada, si fuese adbiento o quaresma, se apagarán las luzes y tendremos exerçiçio de diçiplina, y mientras, dirá la música el miserere y la tal noche no se a de deçir letanía porque en su lugar a de ser el miserere». La hermandad del Cristo de la Salud, cuya festividad principal debía dedicarse a la Invención de la Santa Cruz (3 de mayo), celebraba con una misa cantada con diácono, subdiácono y capilla de música. López MuÑoz, M. L.: Las cofradias de la parroquia de Santa María Magdalena, p. 82, 178-196; Leg. 16 F(a), Archivo de la Curia Eclesiástica de Granada. 
ciones solían revestirse de la misma solemnidad. Además, existían otras celebraciones de carácter ordinario y extraordinario que se realzaban, del mismo modo, con el concurso de la música. Habitualmente, la música está presente en la proclamación de la fiesta (frecuentemente con ministriles en las torres de los recintos eclesiásticos) que se llevaba a cabo el día anterior. La capilla actuaba en las vísperas (primeras y, ocasionalmente, segundas) y en la misa, así como en la procesión en caso de haberla. Las cofradías penitenciales sufragan las agrupaciones musicales que acompañan las procesiones realizadas en la Semana Santa. Procesiones, periódicas o excepcionales, efectuadas por motivos diversos incluyen también capillas de música. Tenemos noticias del acompañamiento musical en las exequias celebradas por el fallecimiento de los hermanos de la cofradía. Por último, salves, misereres, rosarios, etc. requieren la participación de estas capillas. Todo lo cual suponía un importante dispendio para estas instituciones, condicionado por las particulares y concretas situaciones económicas; al mismo tiempo que generaba para los músicos una oferta de considerable interés ${ }^{30}$.

Los componentes de las capillas musicales no permanecerán ajenos al fenómeno social que constituyen las hermandades, necesario para reforzar su identidad grupal y fomentar la sociabilidad de sus miembros. Como colectivo profesional que son, se organizarán para atender sus necesidades asistenciales y subvencionar los gastos, tanto materiales como espirituales, originados por la muerte de cualquiera de sus integrantes. Debieron constituirse en la segunda mitad del siglo XVII, ya que a principios del siglo XVIII todas redactaron nuevos estatutos. Concretamente, la hermandad de la capilla de música de la Capilla Real, también denominada de las Ánimas, se instituyó el 27 de septiembre de 1675. Al igual que el resto de las hermandades, no descuidarán tampoco la vertiente de exteriorización del culto público, aspecto destacado de las cofradías die-

30. Para confirmar lo expuesto, hemos realizado una pequeña prospección en las constituciones de estas cofradías. Así, vemos que la Hermandad de Nuestra Señora de la Consolación (1678), sita en el convento de San Francisco Casa Grande, para su festividad principal, con la advocación del mismo nombre, pagaría una «misa cantada con sus diáconos, sermón, procesión y música con toda solemnidad». La Hermandad de las Benditas Ánimas (1682), servidera en la parroquial de San Matías, decreta que el primer y último domingo del octavario de su fiesta principal «se a de hacer prosezión con la asistencia de sacerdotes y música que pareciere a dicho rector y se an de cantar dos responsos en la yglesia y otros dos en los zementerios». Las fragmentarias cuentas de la importante cofradía de la Veracruz (1685-1713) nos dan noticia de la contratación de capillas musicales de forma regular para distintas festividades. Así, pagan, mensualmente, a «ministriles» que sirven en la procesión de la «cuerda» el tercer domingo de cada mes; a las capillas musicales que acompañaban la procesión del Jueves Santo (en una ocasión se especifica que fueron «tres coros de música») y a las capillas contratadas para el servicio de las festividades de San Juan Bautista y la Santa Cruz. La cofradía de San Sebastián, sita en el hospital del mismo nombre, pagará regularmente a un grupo de ministriles (al menos desde la década de 1580) por acompañar la procesión anual de su santo titular. La Hermandad de Nuestra Señora de Covadonga, sita en la parroquial de Santa María Magdalena, librará pagos a capillas musicales en la festividad de su titular y de San Roque. Especial interés, desde el punto de vista musical, presentan las Constituciones de la Hermandad del Rosario de Nuestra Señora del Triunfo, sita en el convento de la Merced, redactadas en 1698. En ellas, se determina «acompañar a esta Diuina Señora con la deuoción y elogio de su Santo Rosario, cantándolo así en su capilla como por la calles de la ciudad. En su capítulo 6, se especifica que su festividad principal se llevará a cabo el domingo infraoctavo de la Concepción: »se ordena y manda que por lo menos sea indispensable que en dicho día aia su misa y sermón con asistencia de una de las dos músicas de la Catedral y Real Capilla y que asista también a la prozesión de por la tarde que también se ordena sea indispensable». En las exequias realizadas por la muerte de cualquiera de los cofrades se decreta: «es constitución que para las dichas exequias aian de traer una de la música referidas [catedral o Capilla Real] si no es en caso que se halle muy alcanzada la cofradía y que conste ser así». Leg. 11F y 34F(b), Libro de cuentas del Hospital y Cofradía de San Sebastián, Archivo de la Curia Eclesiástica de Granada. Libro de cuentas de la Hermandad de Nuestra Señora de Covadonga, Archivo de la parroquia de Santa María Magdalena. Constituciones y Regla de la Hermandad de Nuestra Señora del Triunfo, Caja B-13, Biblioteca General de la Universidad de Granada. 
ciochescas. Así, la hermandad de la capilla de música de la catedral dotará, en 1713, una misa por sus compañeros fallecidos, que debía celebrarse en la capilla del Santo Cristo de la Columna «en la octaua de los difuntos con toda solemnidad, después de nona». En 1744, el cabildo de la Capilla Real dará licencia a la «hermandad de los músicos» para que celebraran «sus honrras, como todas las hermandades acostumbran», en el altar de la capilla de San Ildefonso. En 1788, se creará en la colegiata del Salvador la cofradía de Nuestra Señora de la Soledad por los capellanes reales y de coro y admitirán en ella al «sorchantre, psalmistas, sachristán, músicos y demás dependientes del choro». Su fiesta principal se celebraría el día de los «Dolores de Nuestra Señora», con una misa solemne a la que asistiría la capilla de música después de las horas ${ }^{31}$.

Jorquera enumera, a continuación de las parroquiales y conventos, los numerosos oratorios, ermitas, capillas y cruces dispersas por toda la ciudad. En general, se limita a citar las fiestas en ellos celebradas, pero, en ciertos casos, también hace explícita la participación musical en estos $\operatorname{actos}^{32}$.

A estas actuaciones de carácter anual, se unen toda una pléyade de fiestas de carácter extraordinario $^{33}$. Como señala María José Cuesta: «no hay más que observar cómo estamos inmersos en una sociedad en que, circunstancias tales como la sequía, las epidemias o las invasiones enemigas, son presentadas como castigos divinos; las victorias, las paces o los nacimientos regios, son bendiciones; y las guerras se presentan siempre como medios para defender el país de los enemigos de la religión. Todas estas connotaciones trascendentes se van a traducir en una serie de ritos, en su mayor parte urbanos; la cantidad de causas susceptibles de estas interpretaciones, hace que dichos ritos se estén repitiendo de forma absolutamente continuada, incidiendo en el mismo aspecto frecuentativo de lo trascendente» ${ }^{34}$.

Aunque pueda resultar un pálido reflejo de la febril actividad desarrollada en estas instituciones, en el apéndice $n^{\circ} 1$ proporcionamos, para cada capilla, todos aquellos desplazamientos que, hasta el momento, han podido ser documentados con fiabilidad. Queremos destacar que

31. Ruiz Jiménez, J.: La colegiata del Salvador..., p. 183-189.

32. Así, en la plazuela de los corredores de la Lonja (dentro de la Alcaicería) se encontraba la imagen de Nuestra Señora de la Encarnación, puesta por la devoción de los mercaderes y corredores de la Lonja. En ella «celébrase salve a la Virgen la víspera de las festividades solemnes con grande fiesta y chanzonetas». Igualmente, en el cobertizo de la calle Abenamar (colación de San Gil) había una imagen de Nuestra Señora con los santos Crispín y Cipriano puesta por la devoción del gremio de zapateros de obra prima de esta calle. Aquí se decía la salve en las grandes festividades de la Virgen «con grande música y chançontas [sic]». Henríquez de Jorquera, F.: Anales de Granada, p. 214-273. Sobre la puerta principal de la Alcaicería, existía una tribuna donde estaba colocada una imagen de «Nuestra Señora con el título de la Assumpción». Todos los sábados del año se le cantaba la salve «con toda solemnidad por medio de la capilla de música de Nuestro Salvador, costeada por sus fieles devotos». Chica Benavides, A. de la, Ave María. Mamotreto... (semana del 5 de noviembre de 1564). La hermandad de Nuestra Señora del Triunfo decretó en sus contituciones (1698): «se cante una salue con música en el simulacro santísimo del Triunfo de Nuestra Señora que esta en el campo» los días de la Concepción, Purificación, Encarnación, Asunción, Natividad de Nuestra Señora y del Rosario. El lugar se refiere al monumento a la Inmaculada, sito ante la puerta de Elvira, actualmente en los jardines del Triunfo. Constituciones y Regla de la Hermandad de Nuestra Señora del Triunfo, Caja B-13, Biblioteca General de la Universidad de Granada.

33. El número de fiestas debía ser tan grande que, en ocasiones, una misma capilla llegaba a servir dos diferentes el mismo día. El cabildo de la catedral llegará a prohibir a su capilla que contratara más de dos fiestas para la misma jornada. AC.C, t. 18 , fol. 112 r; t. 20 , fol. 265 v.

34. Cuesta García de Leonardo, M. José: Fiesta y arquitectura efímera en la Granada del siglo XVIII, Granada, Universidad y Diputación, 1995, p. 20. 
estos datos son muy fragmentarios. Ésto es debido a la irregularidad en la conservación de las fuentes documentales para las distintas instituciones, así como del hecho de que frecuentemente se obvia el lugar de desplazamiento de una capilla, o no se consigna cual es la que actúa en una determinada función. En todo caso, creemos que son lo suficientemente significativos para explicar este fenómeno y la posibilidad de superviviencia no sólo de estas tres capillas estables, sino también de un relevante número de agrupaciones independientes, gracias a sus servicios extravagantes.

Como hemos señalado, el mercado de trabajo para los músicos se veía incrementado con las festividades que generaban las parroquias de los diferentes pueblos que formaban la diócesis. Resulta sorprendente el elevado número de lugares que hemos podido censar en los cuales encontramos algunas de estas capillas (apéndice $n^{\circ} 2$ ). Con toda seguridad, sabemos que este panorama es igualmente parcial, ya que, al igual que ocurre con las salidas en la ciudad, son muy numerosas las ocasiones en que las capillas se desplazaban sin permiso, y no siempre se consignaban los lugares de desplazamiento.

Igualmente, destaca la asistencia a festejos profanos de tipo privado o público ${ }^{35}$. En este último apartado, nos detendremos únicamente en aquellas instituciones que contratan a las capillas eclesiásticas como entidad. Obviaremos los numerosos contactos existentes, a nivel personal, entre los músicos de estas capillas con las actividades musicales civiles vinculadas a la municipalidad o el teatro, permanente fuente de conflicto entre los patrocinadores eclesiásticos y los músicos a su servicio ${ }^{36}$.

35. A modo de ejemplo, podemos señalar la asistencia de los ministriles de la catedral a una comida ofrecida a Juan de Austria (1569), o la de cuatro músicos de esta institución a una fiesta que celebraba Diego Girón «en un lugar de su señorío distante çinco o seis leguas de esta çiudad» (1668). López Calo, José: La música en la Catedral de Granada en el siglo XVI, Granada, Fundación Rodríguez Acosta, 1963, p. 248. AC.C., t. 16, fol. 455v.

36. Tenemos noticias de la participación aislada de músicos de las tres capillas en la banda de música del ayuntamiento, en el teatro, orquesta del Real Cuerpo de Maestranza de la ciudad, «títeres» (1789), «una academia de música que hay en la ciudad» (1758), cantado acompañados de la vihuela en «casas particulares», "paseos», «coches» y «cármenes» (1674). Ruiz Jiménez, J.: La colegiata del Salvador..., p. 375-382. Son frecuentes las prohibiciones de los cabildos a sus músicos para la asistencia a este tipo de actuaciones, para las cuales argumentan que iban en detrimento de sus voces. A modo de ejemplo, la realizada por el cabildo de la catedral, en 1711 , donde se les notifica «que no canten en plazas, calles ni partes públicas de noche, que se escusen de asistir a festejos en casas de particulares». En este sentido, en 1728, la propia capilla de música será la que escribirá al cabildo para exponer las quejas de algunos de sus integrantes «tocante a las funziones de casas particulares, en donde no se les trata con aquel respeto que como a ministros de esta santa yglesia es deuido en donde muchas vezes concurren casualmente con cómicos». El cabildo autorizará a la propia capilla para que multase a aquellos que acudiesen a estas actuaciones, «esceptuando las [casas] de los señores prebendados», quebrantando los decretos que se habían establecido. AC.C., t. 22, fol. 87v; t. 25, fol. 38r. AC.CR., t. 6, fol. 366v; t. 7, fol. 296r; t. 11, fol. 119v. Creemos que estas actividades están relacionadas con su participación en las Academias que se llevaban a cabo en la ciudad. De hecho, en 1662 , se prohibirá al capitular de la Capilla Real, Sancho de Guzmán, que vaya «a las Academias de versos y coplas que se hacían en algunas casas particulares, pues para el apoyo de su ingenio bastantes testimonios auía dado en la composición de otros versos». AC.CR., t. 7, 230v. Hemos localizado varias Academias celebradas en estas casas particulares desde la segunda mitad del siglo xvil. En todas ellas, se recogen los textos que se cantaban. Destacamos las realizadas, en 1707, en casa de D. Pedro Verdugo Ursua y Albornoz, conde de Torrepalma, para celebrar el nacimiento del infante D. Luis Fernando. Ésta se inició con «una tocata italiana de violines y después en dos coros cantada la siguiente letra...». Se recogen citas a otras dos «tocatas italianas»y «música en estilo recitativo». Igualmente interesante, fue la llevada a cabo en casa de D. Luis de Carvajal y Chacón, celebrada las carnestolendas de 1730 que se inició con «vna sonata de violines». En ésta, se cantaron diferentes arias «con flautas dulces», «con violines», «con obúes», «con clarín», «de trompa», etc. Es importante destacar los contactos del conde de Torrepalma con la corte que pudieron influir en la introducción del estilo italiano en la ciudad. Con respecto al instrumental, resaltar que las trompas no aparecen en las capillas eclesiásticas granadinas hasta 1746. B-18-29 (11 y 13), Biblioteca General de la Universidad de Granada; Ruiz Jiménez, J.: La colegiata del Salvador..., p. $296-297$. 
Con respecto ál Ayuntamiento, no queda constancia de que los grupos de ministriles asalariados por la catedral y Capilla Real tuvieran contratos estables con esta institución, a diferencia de aquellos establecidos, por ejemplo, en Baza y Guadix. En estas ciudades, el Cabildo Municipal los subvencionaba conjuntamente con la catedral y la colegiata, por lo que estaban obligados a servir aquellas festividades por ellos organizadas (toros, «carreras», juegos de caña, Corpus, etc. $)^{37}$.

La Universidad de Granada será otro de los organismos que ofertará posibilidades de trabajo a los músicos de las capillas de la ciudad. Ya en sus constituciones, redactadas en 1542, recoge «los derechos de los ministros y música en las fiestas y grados de esta Universidad» que cifraban el pago a los «cantores» en 4 ducados. Se conservan los contratos establecidos por la Universidad de Granada con los ministriles de la catedral, en 1577, y con los de la Capilla Real, en 1619 (por diez años, prorrogable), para la celebración de las funciones religiosas a las que esta institución asistiese, así como para los actos académicos organizados para la obtención de algún grado.

Las fiestas religiosas eran en total cinco. Cuatro fijadas por sus Constituciones: San Lucas, que se celebraba en la catedral; Santa Catalina de Alejandría, en la parroquia de San Justo y Pastor, San Nicolás, en su iglesia, y Santo Tomás de Aquino, en el convento de Santa Cruz la Real (no aparece en el contrato de 1577). La quinta festividad, por acuerdo del claustro, se celebrababa el 1 de noviembre, festividad de San Martín, en las escuelas de la Universidad, con motivo de la elección del Rector. Las actuaciones de los ministriles consistían en tocar desde las ventanas del claustro de la Universidad; así como en las vísperas, en la misas y en las procesiones realizadas (en las cuales irían, generalmente, a caballo). En estos contratos se regulan sus actuaciones en las ceremonias efectuadas para la obtención de los grados de doctor, licenciado, bachiller y magisterio. Sus intervenciones variaban según el grado, y se desarrollaban en el claustro y en los distintos desplazamientos efectuados ${ }^{38}$.

En la primera mitad del siglo XVIII, en distintos vejámenes dados en los actos de concesión de grados en la Universidad y Colegio de Teólogos de la colegiata del Sacromonte, encontramos cantadas con textos satíricos y burlescos. Sólo en una ocasión (1715), se hace alusión a la capilla de música que actuó en esta ceremonia, la de la catedral, y al autor de la «cantada con violines» con la que se dio fin al vejamen, Antonio Navarro, maestro de capilla de la colegiata del Salvador ${ }^{39}$.

37. Ruiz Jiménez, J.: «La música en Granada en la segunda mitad del siglo Xvi». Conferencia dada en el XXVII Curso Manuel de Falla. Sobre la participación regular del Cabildo Municipal de Granada en diferentes festividades realizadas en la ciudad, véase Cuesta García De Leonardo, M. J.: Fiesta y arquitectura efímera..., p. 401-403.

38. Montells y Nadal, Francisco de Paula: Historia del origen y fundación de la Universidad de Granada, Granada, Imprenta de Indalecio Ventura, 1870, p. 99-101; Gila Medina, Lázaro y Gila Medina, M. Josefa: «Los ministriles de la Capilla Real y la Universidad de Granada: aspectos ceremoniales», Cuadernos de Arte de la Universidad de Granada, XXIV, 1993, p. 335-343. Se conservan también libramientos a cantores y ministriles de la Capilla Real entre los años 16211648. Ramos López, P.: La música en la catedral de Granada, vol. I, p. 63-64.

39. La versatilidad de los maestros de estas capillas musicales eclesiásticas debía ser muy grande. Su incursión en la composición de música teatral queda puesta de manifiesto en diferentes ocasiones. En 1703, a petición de los comisarios nombrados para la celebración de la festividad del Corpus Christi, el cabildo de la Capilla Real dará licencia a su segundo maestro de capilla, Manuel Ferreira, para que compusiese la música de los Autos Sacramentales que debían representarse. En 
De este panorama, podemos extraer diferentes conclusiones:

En primer lugar, hay que destacar la variedad de las entidades patrocinadoras de estas fiestas: las propias instituciones en las que se desarrolla la festividad, cofradías y hermandades en ellas servideras, Universidad, Tribunal de La Santa Inquisición, Real Chancillería, Cabildo Municipal, Real Maestranza de Caballería, Universidad de Beneficiados y particulares ${ }^{40}$.

En segundo lugar, creación de un repertorio efímero, principalmente villancicos, tonadas y cantadas sacras para la conmemoracion de acontecimientos de especial significación, que se integra perfectamente en el conjunto de manifestaciones (arquitectura y jardinería, pintura, escultura) y efectos (iluminación, pirotecnia, etc.) que constituyen el lenguaje celebrativo de la «fiesta» ${ }^{41}$.

En tercer lugar, resaltar que la música se convierte en un elemento imprescindible en la pompa de solemnes funciones religiosas que no son más que una faceta del prisma del sentir religioso. Esta vertiente devocional será instrumentalizada por los poderes civiles y eclesiásticos en el proceso de evangelización y aculturación de la población autóctona, que desde el siglo Xvi juega en Granada un papel de especial importancia. La presencia de las capillas musicales, extraordinariamente frecuente por uno u otro motivo, harían que los repertorios tuviesen una enorme difusión entre la ciudadanía, para la cual se constituyen en un importante objeto de atracción ${ }^{42}$. Este hecho contribuiría a la formación de sus propios criterios de interpretación y juicios estéti$\cos ^{43}$.

1725, Antonio Navarro puso música a la obra Cupido y Anteros...ópera a 4, que se cantó en las felicíssimas bodas del Sr. D. Joseph Fernando Pérez del Pulgar... Doña Rosalía de Córdoba, marqueses del Salar... En 1762, Antonio Soriano, maestro de capilla de la colegiata del Salvador, fue el autor de la música del «drama alegórico» Palas y Mercurio, representado por los colegiales del colegio de San Bartolomé y Santiago en la celebración del «nuevo patronato» de la Inmaculada Concepción. En 1785, Esteban Redondo, organista de la Capilla Real, pondrá música a la serenata Los Meritos Reunidos, que se cantó en el colegio de San Bartolomé y Santiago para celebrar la concesión del obispado de Canarias a D. Antonio Martínez de la Plaza, colegial que había sido de esta institución. Desafortunadamente, sólo se conservan los textos de estas composiciones. C-36-48 (10-12, 20), C-19-61 (18), Biblioteca General de la Universidad de Granada; 1564 (12) Biblioteca y Hemeroteca de la Casa de los Tiros; AC.CR, t. 11, fol. 119v; Ruiz Jiménez, J.: La colegiata del Salvador..., p. 609.

40. A modo de ejemplo del mecenazgo particular de estas festividades, citaremos la fundación de un octavario anual para la «limpia y pura concepción de María Santísima» realizada por el arzobispo de Granada, Alonso Bernardo Gutiérrez de los Ríos, en 1691. Debía celebrarse en el convento de Jesús y María, cada uno de los días del octavario, una misa cantada. Entre las claúsulas de la fundación, se recoge expresamente: «Asimismo de asistir en todos los días del dicho octauario la música de la capilla de dicha nuestra santa yglesia cathedral a quien señalo y mando se le de lo que es costumbre por cada punto ajustándolo con la economía posible y con la misma puntualidad que todo lo demás». Leg. 45F, Archivo de la Curia Eclesiástica de Granada.

41. Sobre los distintos tipos de fiestas, su lenguaje y elementos celebrativos, véase Ramos López, P.: La música en la catedral de Granada en la primera mitad del siglo XVII..., p. 18-48; CuESTA GARCía DE LeONARDo, M. J.: Fiesta y arquitectura efimera..., p. 9-48.

42. Constata este hecho, a modo de ejemplo, la decisión tomada por el cabildo de la Capilla Real, en 1702, de cantar «perpetuamente» los villancicos de Navidad y San Juan Evangelista en un coro portátil dispuesto debajo del coro alto. Señala que «antiguamente concurría mucha gente a los maitines de Navidad y San Juan Evangelista y que de algunos años a esta parte sólo tres o quatro hombres y otras tantas mugeres y que algunos años persona ninguna». El problema era debido a que el coro estaba en «alto y los villancicos se cantan en él y la gente no los oye desde el cuerpo de la yglesia». AC.CR., t. 11 , fol. $107 \mathrm{v}$.

43. Son frecuentes las alusiones a la calidad del repertorio y de las interpretaciones de las capillas en las descripciones de estas festividades. Apoyan esta hipótesis numerosas referencias al interés por la novedad de las composiciones y a las demandas de los contratantes de estas capillas, algunas de ellas ya recogidas en el texto de este artículo y en el apéndice $\mathrm{n}^{\circ} 1$. Así, en 1653, cuando el cabildo de la Capilla Real admita a Pedro de Soria cantor y arpista explicitará: que «era muy a propósito i necesario... así por su voz... como por el tocar de la harpa, cosa de que necesitava tanto la capilla por estar ya tan 
En cuarto lugar, podemos apreciar una gran diversidad en la composición de las agrupaciones que asistían a las fiestas: encontramos desde la capilla completa a grupos de ministriles o cantores en número variable.

En quinto lugar, se pone de manifiesto que servían, principalmente, en las vísperas (primeras y segundas), la misa y las procesiones, que juegan un especial papel en el proceso de sacralización del espacio público ${ }^{44}$. Actúan también en salves, misereres, jubileo de las cuarenta horas, entierros, etc.

En sexto lugar, se constata una alternancia de las capillas musicales que sirven en un determinado lugar. Los contratos con ellas podían realizarse para una festividad concreta o por un cierto período de tiempo. Este hecho vendría condicionado por la disponibilidad de las distintas capillas y por los recursos económicos del contratante, ya que existía una jerarquía de las mismas derivada de sus propios honorarios (en orden decreciente: catedral, Capilla Real y colegiata del Salvador).

El más permisivo de los tres cabildos, tanto para el desplazamiento dentro como fuera de la ciudad a servicios religiosos y profanos de su capilla, será el de la colegiata del Salvador. Esta institución, consciente de los parcos salarios ofrecidos a sus músicos, liberalizará estas salidas, imprescindibles para la supervivencia de los mismos. Ésto está, creemos, directamente relacionado con la mayor profusión de las plazas no asalariadas en esta capilla, ya que parece existir una relación inversamente proporcional entre el número de plazas no asalariadas y los salarios asignados a las plazas con renta. Hemos apuntado que, con mucha frecuencia; los músicos se desplazaban a pesar de las prohibiciones decretadas por sus cabildos, ésto era debido a que los ingresos percibidos en estas funciones eran tan rentables que preferían asistir a ellas y pagar el importe de las multas impuestas. El cabildo de la Capilla Real, en un intento de frenar la trasgresión a estos decretos, llegará en varias ocasiones a despedir músicos por este motivo o a tomar la determinación de suspenderlos un mes de entrar en el coro y percibir durante este período los ingresos correspondientes ${ }^{45}$.

En la segunda parte de este artículo, nos centraremos en el estudio de las plazas no asalariadas que se integraban en las distintas capillas musicales estables de la ciudad.

En el apéndice $n^{\circ} 3$, podemos ver las diferentes tipologías de plazas existentes en las tres capillas musicales granadinas que, salvo alguna importante excepción (capellanías reales), coin-

introducida la harpa i no gustar ya la gente de la música en no aviendo harpa». En 1687, también en la Capilla Real, se señala que «como la capilla va disminuida [a las fiestas] los que las conciertan no quieren pagar lo concertado y no los llaman otras veces». En 1692, el cabildo de la Capilla Real dará permiso para que el organista asista «a las fiestas de percanzes con el instrumento referido antes [clave] si les podía resultar a los músicos más fiestas por parecer bien la música del clavizímbalo». En la catedral, en 1736, se entablará una fuerte polémica cuando el cabildo decida suprimir el arpa «en atención de no usarse ya de dicho instrumento en capilla de música, ni aun fuera de ella, por no ser necesario». Por contra, la capilla reitera una y otra vez «la grande necesidad que tenían para las funciones de fuera de la iglesia de un arpista». Se solucionará contratando un arpista sólo con «parte en fiestas» para sus actuaciones en el exterior. AC.CR., t. 6, fol. 51v; t. 9, fol. 252r.; t. 10, fol. 162v. AC.C., t. 26, fol. $260 v, 282,374$ r.

44. En 1715, el cabildo de la catedral acordó que «los ministriles de violín y violón los lleuen como a las iglesias a las procesiones, para vsar de ellos sólo quando pasare [sic, ¿parase?] la procesión y la música cantare los villancicos, vsando de ellos quando lo pidieren los papeles y según lo dispusiere el que hechare el conpás». AC.C., t. 22, fol. 321v.

45. AC.CR., t. 12, fol. 26r, 235v; t. 13, fol. 184r; t. 16, fol. $171 \mathrm{v}$. 
ciden con las que encontramos en la mayor parte de los recintos eclesiásticos de la geografía española.

Las tres capillas musicales de Granada incluyen en su composición, además de las tipologías señaladas, tres categorías de «plazas» que podemos clasificar según los ingresos derivados de las mismas: ejercitantes, media parte en fiestas y parte entera en fiestas. Su característica principal será la no percepción de rentas fijas por parte de la obrería de sus instituciones.

En primer lugar, hay que señalar que su presencia empieza a detectarse desde finales del siglo XVII, para alcanzar su máximo apogeo durante el siglo XVIII. Por medio de este procedimiento, se aumentaba el número de integrantes de la capilla de música, necesario por la evolución del repertorio y para poder dividir la capilla para sus actuaciones en el exterior, sin necesidad de gravar a la fábrica.

De las diferentes tipologías de plazas existentes en las capillas, precisamente serán éstas, que no gozan de salario, las que presentan mayores dificultades para su estudio, sobre todo, en el sentido de saber exactamente en cada momento cuál es el número de las mismas que se integran en la capilla. El problema radica en el hecho de que al no percibir una renta no aparecen nunca consignadas en las nóminas de salarios de los empleados en estas instituciones. Por lo tanto, sólo los autos capitulares, o memoriales de solicitudes personales, que no siempre son todo lo sistemáticos que desearíamos, nos aportan alguna información sobre su existencia. Con frecuencia, estas fuentes no precisan si las solicitudes de aquellos que querían ingresar en las mismas eran aceptadas, y en qué momento las dejaban o promocionaban de unas a otras.

Hay una característica común a estos tres tipos de «plazas»: su provisión por medio de un examen. El juez será sistemáticamente el maestro de capilla o, en su ausencia, la propia capilla de música, que siempre luchó por mantener una independencia del cabildo en la gestión de sus actuaciones fuera de sus recintos patrocinadores ${ }^{46}$. En caso de no alcanzar los mínimos requeridos eran rechazados. En determinadas ocasiones, estos solicitantes se presentan ante los cabildos como «profesores de música», lo que hace suponer que ya poseían un buen nivel musical ${ }^{47}$.

Las plazas de ejercitantes están relacionadas con el proceso de aprendizaje, el cual no terminaba al finalizar su estancia como seises y su posterior adiestramiento vocal o instrumental. Las tres capillas musicales de la ciudad contemplan esta figura de los ejercitantes, aplicable tanto

46 En este sentido, es muy interesante el pleito establecido entre unos de los miembros de la Hermandad de los músicos de la Capilla Real (establecida en 1675), el bajonista José Moreno, y el cabildo de esta institución, desencadenado por la decisión de que el protector de la capilla tuviera en su poder una de las tres llaves del arca de la Hermandad, lo cual suponía un control sobre sus actividades. Ruiz Jiménez, J.: La colegiata del Salvador..., p. 188-189.

47. Este hecho puede venir ejemplificado por el caso de Juan Guitarte, organista, arpista y clavecinista de la Capilla Real. Se le concede la parte en fiestas de la capilla el 26 de abril de 1743. Permanecerá en esta posición hasta que se le otorgue el salario correspondiente al primer arpista el 13 de noviembre de 1750 . El 1 de octubre de 1756 se le nombrará maestro de capilla interino. Por su curriculum sabemos que «desde la edad de doce años empezó a aprender las reglas de composición en la ciudad de Zaragoza con D. Luis Serra, maestro de capilla de la metropolitana del Pilar». A los 17 años (1739) opositó a la plaza de organista y maestro de capilla de la catedral de Barbastro, «en que salió aprobado en igual grado que el que se llevó la plaza», con un informe muy favorable. Vemos, por lo tanto, que cuando accede a la «parte en fiestas» de la Capilla Real tenía 21 años y gozaba ya de unos años de experiencia. AC.CR., t. 16, fol. 8r; t.17, fol. 74v, 566v, 632r; RUIZ JimÉnEZ, J.: La colegiata del Salvador..., p. 221-222. 
a cantores como a instrumentistas, de gran importancia durante los siglos XVIII y XIX. Todos ellos se caracterizan por su participación activa en sus respectivas capillas sin percibir ningún salario por sus servicios en ellas. Irán perfeccionándose en la práctica vocal o instrumental, hasta encontrarse con el nivel adecuado para poder acceder a alguna de la plazas con renta de sus propias capillas, o de otras en la ciudad o fuera de ella. También es un hecho frecuente que ocupen estas plazas músicos perfectamente formados, a la espera de vacantes en las distintas instituciones. Ésto es especialmente significativo en la catedral.

La etapa de ejercitante llegaba a durar desde unos meses a varios años, percibiendo únicamente, de forma periódica, alguna gratificación por vía de ayuda de costa o, en ciertos casos, ocupando alguna plaza de acólito. Durante este tiempo, podían, además, aplicarse al estudio de otro instrumento diferente al que tocaban en el momento de su recepción, cuya elección estaba condicionada, generalmente, por las necesidades de la capilla. La docencia se llevaba a cabo por los propios asalariados de las distintas instituciones y puede documentarse perfectamente en la Capilla Real, donde existen verdaderos maestros dedicados a la formación de nuevos instrumen$\operatorname{tistas}^{48}$.

Consideramos que la importancia de estas «plazas» es fundamental, ya que llegarán a convertirse en la principal vía para adquirir la práctica necesariá que permitiera a los músicos acceder a las plazas con dotación económica en las diferentes capillas. La existencia de esta figura de ejercitante o meritorio modificará, al igual que los otros dos tipos de plazas, la composición real de las propias capillas de música tanto cualitativa como cuantitativamente ${ }^{49}$.

La denominación de las plazas consignadas como «medias partes» y «partes enteras» dimana del producto obtenido de la capilla de música por los individuos que gozaban de esta categoría, en razón a su servicio en las festividades contratadas fuera de sus recintos patrocinadores. Estas plazas eran muy necesarias, sobre todo, cuando la capilla se dividía para salir a servir una fiesta, y será el motivo de que, en ocasiones, se asignen en función de estas necesidades ${ }^{50}$.

Todo parece apuntar a que las rentas procedentes de estas actuaciones constituyen la fuente principal de ingresos para los músicos del Salvador. Esto posibilitaba que muchos de sus integrantes vivieran, durante los primeros años de formación, con las obvenciones procedentes de la media parte o parte entera percibida por este concepto. La cantidad correspondiente a una parte en fiestas, como podemos ver en el apéndice $n^{\circ} 4$, mantendrá una relativa estabilidad. Es interesante destacar qué proporción constituía la parte en fiestas en el montante global de los ingresos

48. Juan Moreno (bajón), Diego de la Riva (violín y oboe), Agustín Quero (violín), Andrés Yepes (contrabajo), Gerónimo Valero (violín), Braulio Eugena (violín). Ruiz Jiménez, J.: La colegiata del Salvador..., p. 220.

49. Numerosos ejemplos pueden seguirse en el apéndice $n^{\circ} 1$ de nuestra tesis doctoral: Fichas Biográficas. Ruız JiménEz, J.: La colegiata del Salvador..., p. 413 ss.

50. Los ejemplos son bastante numerosos. En la catedral, las admisiones, con parte en fiestas, de un tenor (1681), arpistas $(1683,1693,1736)$, clavecinista (1733), etc. En 1756, la capilla de música de la Capilla Real se encuentra con el problema de la falta de un instrumento que toque el bajo y de un violín cuando la capilla se divide. Exponen que es muy difícil cubrir estas bajas invitando a otros músicos «pues muchas veces se escusan y otras no quieren sino a costa de un crecido estipendio», y que esta circunstacia hacía que se estuviese produciendo una decadencia en las fiestas que necesitaban servir para completar sus rentas. Solicitarán que se cubran las dos partes y media que había vacantes en ese momento. AC.C., t. 18, fol. 180v, 305v; t. 26, fol. 58r, 258r, 260v, 281r, 282r, 282v, 374r. AC.CR., t. 11, fol. 75v; t. 17, fol. $573 \mathrm{v}$. 
obtenidos. Para ello, tomaremos un ejemplo extraído de los edictos emitidos por la catedral, en 1715, para la provisión de una de las plazas de bajonista de su capilla. En esta convocatoria, la institución que mejor remuneraba a sus músicos, en ese momento, ofrecía un salario de 100 ducados y 12 fanegas de trigo, «y la parte entera en las fiestas a que fuere la capilla que se rreputa por otros zien ducados». En este caso concreto, podemos afirmar que la parte en fiestas suponía una cantidad equivalente al salario percibido en dinero ${ }^{51}$. Si tenemos en consideración que existen motivos para suponer que la capilla que debía servir un mayor número de fiestas era la de la colegiata, habría que pensar en una cifra similar, al menos en torno a los 100 ducados anuales, como la cantidad que correspondería en concepto de parte de fiestas a los individuos de la capilla de música de esta institución.

En la Capilla Real y especialmente en la colegiata del Salvador, es muy frecuente la promoción desde la plaza de ejercitante a la de media parte, parte entera y posteriormente a una plaza asalariada, pero ésto no impide que se produzca el ingreso directo a cada una de ellas, o que su promoción no implique pasar por los diferentes estadíos. El tiempo de permanencia en cada una de ellas es muy irregular. Éste dependerá no sólo de la mejora en el nivel de ejecución de cada músico en particular, sino también de la disponibilidad de vacantes o de sus propias posibilidades de ascenso en otras capillas musicales ${ }^{52}$.

A continuación, queremos ejemplificar uno de los aspectos que nos parecen de mayor relevancia en relación a estas plazas no asalariadas, y que ya citábamos anteriormente. Se trata de la modificación de las plantillas de las distintas capillas musicales, cuyo interés es indiscutible a la hora de abordar el estudio de la interpretación de los diferentes repertorios. Esta modificación no sólo amplía numéricamente la capilla, sino que introduce, en muchas ocasiones, una mayor diversidad instrumental en las mismas. Hay que incidir en la imposibilidad de cuantificar, de forma precisa, el número de estas plazas en cada momento, por lo que los ejemplos que incluimos en el apéndice $n^{\circ} 5$ son una aproximación a este fenómeno.

La capilla musical de la colegiata estaba constituida por 12 plazas asalariadas que incluían al maestro de capilla, pero no al organista, sochantres ni seises. Las cifras que presentamos en el apéndice $n^{\circ} 5$ nos proporcionan el número real de los componentes de la capilla en diferentes fechas, lo que nos da una idea del número de plazas no asalariadas incorporadas en ella.

La capilla de música de la Capilla Real, según las constituciones de 1758, debía contar con 20 plazas dotadas de renta. En el apéndice $n^{\circ} 5$, podemos ver que el número total de músicos de la capilla estaba incrementado, en este momento, al menos en 5 plazas no asalariadas.

51. El valor de las 12 fanegas de trigo (muy variable en función de las cosechas) oscilará durante el período comprendido entre 1736-1771, entre un mínimo de 6.528 maravedís (aproximadamente 17,5 ducados) en 1743, y un máximo de 20.808 maravedís (aproximadamente 55,5 ducados) en 1765. Los músicos de las distintas capillas percibían otros ingresos suplementarios, de difícil cuando no imposible cuantificación, por actividades de carácter extraordinario desarrolladas en sus instituciones. Ruiz JimÉNEZ, J.: La colegiata del Salvador..., p. 175, 384-395.

52. Ruiz Jiménez, J.: La colegiata del Salvador..., p. 224-225. 
Para concluir y hacer incidencia en la modificación de las plantillas de las distintas capillas, no podemos dejar de contemplar la figura de los músicos invitados. Desde principios del siglo XVII, se aprecia como de forma creciente se producen refuerzos a las plantillas de las distintas capillas de la ciudad con músicos procedentes de las restantes, por motivo de celebraciones de especial relevancia dentro del año litúrgico. Frente al hecho extraordinario de la reunión de las capillas de la catedral y Capilla Real para la conmemoración de las honras celebradas por el fallecimiento de los diferentes monarcas o sus familiares, los refuerzos concretos son muy abundantes. También es frecuente que músicos de una capilla se integren en otra cuando ésta se desplaza al exterior. Este hecho genera una interrelación entre las tres capillas musicales granadinas que está directamente en conexión con los circuitos de promoción existentes en ellas ${ }^{53}$.

Hemos intentado trazar un panorama del mercado musical que la diócesis de Granada ofrecía a los integrantes de las tres capillas musicales eclesiásticas presentes de forma estable en la ciudad. Esta demanda posibilitó no sólo la existencia de las mismas, sino también la creación de pequeñas agrupaciones musicales de vida más o menos efímera que subsistirán gracias a ella. Nos ha permitido, igualmente, constatar la descentralización del fenómeno musical religioso, disperso en el entramado urbano, que favoreció la creación de un repertorio ocasional y su difusión entre la ciudadanía, que estará en contacto con él de forma habitual. En relación con este fenómeno, aparecen una serie de plazas no asalariadas en las plantillas de estas capillas musicales, que presentan un gran interés tanto desde su vertiente formativa, como modificadora de sus composiciones cualitativas y cuantitativas, especialmente desde finales del siglo XVII hasta bien entrado el siglo XIX.

53. Ruiz Jiménez, J.: La colegiata del Salvador..., p. 384. Los respectivos cabildos pagarán una cantidad estipulada por cada una de las asistencias, generalmente oscilante, durante el siglo XviII, entre 10 y 15 reales. Aunque el dato que traemos a colación corresponda a un período especialmente conflictivo de la capilla de música de la catedral, en pleno proceso de reorganización, no deja de resultar significativo. Podemos señalar que durante los años 1813 y 1814 se invitaron entre 3 y 8 músicos para determinadas festividades, alcanzando la cifra de 905 las asistencias extraordinarias. AC.C., t. 43, fol. 17r. Leg. 139, pieza 2, leg .169, leg. 170, Archivo de la catedral de Granada. Libros 2086 y 2088, Archivo de la Capilla Real de Granada. Ms. 82, Archivo de la colegiata del Salvador. 
APÉNDICE No 1 : SALIDAS DE LAS CAPILLAS MUSICALES A RECINTOS ECLESIÁSTICOS DE LA CIUDAD ${ }^{54}$

\author{
COLEGIATA DEL SACROMONTE:
}

- Catedral: (1600), (1601) cantores y ministriles, (1721) misa, (1730) Festividad de San Cecilio ${ }^{55}$, (1739) Traslado de los restos del arzobispo Pedro de Castro. Misa y procesión (responso de difuntos), (1748).

- Capilla Real: (1750) Vísperas de San Cecilio. 4 músicos, (1757).

COLEGIO DE SAN PABLO (Compañía de Jesús):

- Catedral: (1593), (1610), (1623), (1640) Procesión de desagravio a Nuestra Señora, (1650) Festividad a la Inmaculada Concepción. Misa, (1716) Beatificación de Juan Francisco Regis. 6 villancicos. Música de Gregorio Portero (textos), (1727) Diferentes patronos. Canonización de San Luis Gonzaga y San Estanislao Kostka. Manifestación del Santísimo Sacramento por las tardes. 6 villancicos. Probablemente música de Gregorio Portero (textos) (8 días) ${ }^{56},(1746)$, (1752) Congregación del Espíritu Santo. Jubileo de las 40 horas (tres días de carnestolendas).

- Capilla Real: (1641) Jubileo, (1671) Distintos patrocinadores. Canonización de San Francisco de Borja. Misa y vísperas. 9 Villancicos. Probablemente música de Antonio Vargas Machuca (textos) (8 días $)^{57}$, (1692) Congregación de los siervos del soberano Espíritu. Festividad de las 40 horas. 8 villancicos (textos). Música de Alonso de Blas y Sandoval (3 días), (1726) Noticia del decreto de canonización de San Luis Gonzaga y San Estanislao Kostka, (1727) Capilla Real. Canonización de San Luis Gonzaga y San Estanislao Kostka. Misa. Villancicos. Probablemente música de Alonso de Blas y Sandoval.

- Capilla de Juan Fernández: (1625) Hermandad del Espíritu Santo. Carnestolendas. 3 cantores y 5 ministriles (3 días).

54. Los datos consignados en los apéndices $n^{\circ} 1$ y 2 proceden, fundamentalmente: de las actas capitulares de las tres instituciones con capillas musicales estables, libros de fábrica y gastos de parroquias, monasterios y cofradías, pliegos de villancicos, folletos con descripciones de fiestas y publicaciones periódicas. La localización de estas fuentes: Archivos de la catedral, Capilla Real y colegiata del Salvador, Archivo de la Curia Eclesiástica de Granada, Biblioteca General de la Universidad de Granada, Biblioteca de la Universidad de Sevilla. Biblioteca de la Facultad de Teología, Biblioteca y Hemeroteca de la Casa de los Tiros, Archivo Histórico Nacional y Biblioteca Nacional.

55. Se les permitirá ir «porque los villancicos que el señor maestro de capilla [Gregorio Portero] tiene dispuestos son tan cómodos que acabado el de la Epístola no hazen falta algunos yndividuos de dicha capilla por ser los villancicos del Ofertorio y Alzar con vna voz sóla y los violines y el resto de la misa de facistol». AC.C, t. 25, fol. 221r.

56. El útimo día del octavario (lunes, 20 de octubre de 1727), en el patio del colegio se dispuso un «tablado menor para el coro de música». Alternó la declamación de poemas con la interpretación de cantadas y se bailó una «contradança inglesa». Se conserva el texto de una de estas cantadas profanas: «Diálogo armónico entre Venus, Daphne y la Ninfa Iris». Desconocemos quién fue el autor de la música y los encargados de su ejecución. B-51-95, Biblioteca General de la Universidad de Granada.

57. Resulta creible, por lo inusual y por aparecer en dos crónicas diferentes, la alusión a la calidad de la capilla de música: «en la música tuvo gran fortuna la fiesta, porque demás de asistirle la de la Real Capilla que siempre es buena, en esta ocasión se halló con dos vozes peregrinas y de singular destreza que quince días antes fueron admitidas y se estrenaron con este octauario, no dexando que hazer a los maestros más venerados en la armonía»; «la música de la Capilla Real sobresaliendo en ella entre sus bien templados instrumentos y realçadas vozes las de vn chicuelo tan tiple que se juzgaua vn canario en los quiebros y en los contrapuntos vn ruyseñor, causando en el auditorio nouedad lo diestro tanto como de su voz lo primoroso y suaue». Una de las tardes se representó una comedia «symbólica del santo», «sirvió de saynete no sólo la escogida música que por nueua grangeó más el aplauso sino la dança de torneos militares que jugaron quatro ayrosos estudiantes». Desconocemos quién tocó en ese entremés. C-33-99 (1 y 2), Biblioteca General de la Universidad de Granada. 


\section{CONGREGACIÓN DE SAN JUAN DE DIOS:}

- Catedral: (1732), (1757) Diferentes patrocinadores. Inauguración de su nuevo templo y traslado de los restos de San Juan de Dios. Vísperas, misa, procesión, siestas y novena (varios días) ${ }^{58}$, (1764) Fray Alonso de Jesús y Ortega. Fiesta de la Concepción. Fiesta y salve (2 días).

- Capilla Real: (1757) Inauguración de su nuevo templo y traslado de los restos de San Juan de Dios. Misa y 3 villancicos compuestos para la ocasión (textos). Música de Antonio Caballero ${ }^{59}$.

CONVENTO DE JESÚS Y MARÍA (capuchinas):

- Catedral: (1688), (desde 1692) Arzobispo Alonso Bernardo Gutiérrez de los Ríos. Octavario de la Concepción. Misa (8 días), (1722), (1746).

- Sin especificar capilla: (1706) «Villancico para el día del Señor S. Miguel» (texto).

CONVENTO DE LA CONCEPCIÓN: (terciarias franciscanas):

- Catedral: (al menos 1566), (1760) Real Maestranza de Granada ${ }^{60}$. Exequias de María Amalia de Sajonia. Vigilia y misa, (1761) 3 cantores y 3 ministriles.

CONVENTO DE LA MADRE DE DIOS (comendadoras de Santiago):

- Catedral: (1728-1729), (1740), (1796-1797) Festividad del apóstol Santiago. Maitines, segundas vísperas y misa.

- Sin especificar capilla: (al menos 1604-1630) Festividad de Santiago, Ascensión y Corpus.

58. Las alusiones musicales en la descripción de estas festividades son muy numerosas. Traeremos a colación aquellas de mayor interés. Todos los días «desde la siete de la mañana estuvo la música tocando sonatas y conciertos repartida en el coro y tribunas de la iglesia». El 27 de octubre se cantó una «missa nueva» traída de Roma (a costa del Padre General de San Juan de Dios): «la más sonora, con dobles instrumentos, assí de boca como de arco, que aun estando tan completa de ellos y de voces dicha capilla, fue preciso valerse de otra para poderla oficiar». Por las tardes, se exponía el Santísimo y la capilla de música de la catedral interpretaba «conciertos, arias y villancicos» hasta que empezaba la novena a San Rafael. «teniendo en los intermedios conciertos, obertura, villancicos y arias». El segundo día de la octava, la capilla «completa de voces e instrumentos comenzó a oficiar la missa» de nueva composición, a cargo del Tribunal de La Inquisición. El cuarto día, se interpretaron en la misa villancicos nuevos. El quinto día, «acabada la Epístola, se cantó por la música en bien concertados coros, un bello villancico con todo golpe de instrumentos, que a el intento previno el director de ella, y después al Ofertorio se oyó un aria de especialissimo gusto y alta idea, y de no menos un motete, cuyas claúsulas sonoras suspendían el espíritu y lo inclinaban a la más tierna devoción: cantose este al tiempo de elevar la Sagrada Hostia, y duró hasta el de entonar el preste el Pater Noster, y en los demas intermedios que huvo se tocaron varias agradable sonatas en el nuevo órgano». El sexto día, Fray Alonso de Jesús y Ortega, padre general de la orden dio una misa para que se cantara: «es su composición por author romano de un rumbo especial...». El septimo día, Juan Reverti, uno de los miembros del Colegio de Abogados de la Real Chancillería «costeó la nueva música que se adaptó a la sacra letra de la Missa y villancicos que en ellas se cantaron». Para una fiesta particular que celebró la congregación, después de la octava, Fray Alonso de Jesús «encargó en la Corte Romana la composición de una nueva Missa en música a uno de los maestros de mejor opinión». La dio al maestro de capilla de la catedral que invitó a voces e instrumentos que le faltaban para «completar las treinta y seis partes de que se compone esta obra», causando una gran admiración entre los asistentes. También hubo en las celebraciones tres villancicos compuestos por el padre fray Domingo Pérez de Moya, de la comunidad de San Juan de Dios (textos). Durante estos festejos, se representó «un coloquio o alegórico auto» en la nueva enfermería de religiosos, con intermedios musicales. PARra y Cote, Fr. Alonso: Desempeño el más honroso... y relación histórico-panegyrica de las fiestas de la Dedicación del Magnífico Templo de la Purísima Concepción de Nuestra Señora del Sagrado Orden de la Hospitalidad de N. P. San Juan de Dios... Madrid, Imprenta de Franciso Xavier García, 1759.

59. En el archivo de música de la Capilla Real, se conserva la música de uno de ellos. Se trata de la «cantada sola, con violines, al señor San Juan de Dios» que se interpretó en el Ofertorio.

60. En este convento, celebraba habitualmente esta importante institución granadina sus «piadosas funciones». A31-179 (3), Biblioteca General de la Universidad de Granada. 
CONVENTO DE LA MAGDALENA (agustinas recoletas):

- Capilla Real: (1753).

- Sin especificar capilla: (1727) Profesión de la religiosa Teresa María de Santa Inés. 2 villanci$\cos ($ textos).

CONVENTO DE LA TRINIDAD (trinitarios calzados):

- Capilla Real: (1765) Congregación del Dulce Nombre de María. Jubileo de las 40 horas (3 días de carnestolendas).

- Sin especificar capilla: (1764) Maitines del nacimiento de Nuestra Señora.

CONVENTO DE LOS MÁRTIRES SAN COSME Y SAN DAMIÁN (carmelitas descalzos):

- Catedral: (1620) Dedicación de la nueva iglesia. Misa pontifical, (1796) Cofradía de Nuestra Señora del Sepulcro. Procesión para colocar el Santísimo en el altar de la cofradía y misa.

- Capilla Real: (1591) Se señala que anualmente sirven con los músicos de esta institución vísperas y misa de los Santos Mártires San Cosme y San Damián. Se oficia en el coro y altar mayor.

- Sin especificar capilla: (1675) Octava consagrada a San Juan de la Cruz. 3 villancicos (textos), (1703) Gremio de cirujanos y boticarios. Mártires Cosme y Damián. 4 villancicos ${ }^{61}$ (textos), (1717), (1720), (1721), (1723) Música de Gregorio Portero, (1724), (1727), (1728) Música de Antonio Navarro ${ }^{62}$, (1730), (1732), (1735), (1738), (1739). Todos los años patrocinadas por el Ilustre Colegio de Abogados de la Real Chancillería. 3-4 villancicos anuales (textos).

CONVENTO DE NUESTRA SEÑORA DE GRACIA (trinitarios descalzos):

- Catedral: (1640) Real Chancillería. Fiesta de desagravio de Nuestra Señora (8 días).

- Capilla Real: (1699) Fiesta de la Santísima Trinidad. Música compuesta para la ocasión, probablemente por Alonso de Blas Sandoval (3 días), (1719) Ministriles.

- Colegiata del Salvador: (1715).

- Sin especificar capilla: (1738-1739) Hermandad de caballeros receptores de la Real Chancillería. Festividad de la Asunción (Nuestra Señora de Gracia). 3 villancicos cada año (textos). Música de Matias Barragán (1738) ${ }^{63}$.

CONVENTO DE NUESTRA SEÑORA DE LA CABEZA (carmelitas calzados):

- Catedral: (1564) Misa y procesión. Ministriles, (1566) Cofradía. Ministriles, (1601) Ministriles, (1734), (1764) Patrón «un devoto», (1797) Restablecimiento del culto a la Virgen de la Cabeza.

61. El tercero de los villancicos «sólo con violines». Resulta interesante debido a que las primeras noticias de este intrumento en las capillas musicales de la ciudad datan de 1707 en la catedral, 1708 en la Capilla Real y 1716 en la colegiata del Salvador. Ruiz Jiménez, J.: La colegiata del Salvador..., p. 299-300.

maestro.

62. Posiblemente, al menos este año, sirviera la capilla de la colegiata del Salvador ya que Antonio Navarro era su

63. Es posible que, al menos en 1738 , fuera la capilla de música de la catedral la encargada de interpretar estos villancicos, ya que Matias Barragán era, en esas fechas, segundo organista de esta institución. Patrocinada por «ministros» de la Real Chancillería, tenemos noticia de esta festividad, con su octavario, al menos desde la primera mitad del siglo xvII. Henríquez de Jorquera, F.: Anales de Granada, p. 241. La Real Chancillería celebraba siempre sus festividades religiosas en este convento. Cuesta García de Leonardo, M. J.: Fiesta y arquitectura efímera..., p. 29-30. 
- Capilla Real: (1764) Novena de Nuestra Señora del Carmen (tardes).

- Sin especificar capilla: (1707) 6 villancicos a Nuestra Señora del Carmen (textos) ${ }^{64}$.

CONVENTO DE NUESTRA SEÑORA DE LORETO (agustinos descalzos):

- Catedral: (1694) Diferentes patronos. Dedicación del nuevo templo. Vísperas, misa y procesión (varios días). Se conservan los textos de parte de los villancicos, letras y quintillas que se cantaron.

- Capilla Real: (1694) Dedicación del nuevo templo. Se conserva el texto de una de las letras.

\section{CONVENTO DE NUESTRA SEÑORA DE LOS ÁNGELES (franciscanas):}

- Capilla Real: (1757).

CONVENTO DE SAN AGUSTÍN (agustinos calzados):

- Catedral: (1566) Ministriles, (1646) Cofradía de San Roque. Vísperas, misa y procesión.

- Capilla Real: (1647) Cofradía de San Roque. Torre, vísperas, misa y procesión, (1659) Fiesta de Santo Tomás de Villanueva. Villancicos compuestos por Gregorio Pérez de Moradilla.

- Colegiata del Salvador: (1629) Cofradía de San Roque. Fiesta de San Roque. Torre, víspera, misa y procesión, (1646) Cofradía de San Roque. Fiesta de los Difuntos. Misa y vigilia.

CONVENTO DE SAN ANTONIO DE PÁDUA (franciscanos descalzos):

- Capilla Real: (1691).

CONVENTO DE SAN FRANCISCO CASA GRANDE (franciscanos observantes):

- Catedral: (1615) Hermandad de la Inmaculada Concepción. Vísperas y misa. «Chanzonetas» compuestas por Luis de Aranda ${ }^{65}$, (1672) Misa cantada.

- Capilla Real: (1650) Diversos patrocinadores. Fiestas a la Inmaculada Concepción. Misa, completas (tercer día), procesión (último día) (8 días), (1690) Hermandad de la Veracruz. Festividad de San Juan. Festividad de la Santa Cruz. Vísperas y Misa, (1694-1695) Hermandad de la Veracruz. Festividad de la Santa Cruz, (1696) Hermandad de la Veracruz. Procesión del Jueves Santo, (1698) Hermandad de la Veracruz. Festividad de la Santa Cruz, (1713) Hermandad de la Veracruz. Festividad de la Santa Cruz.

CONVENTO DE SAN FRANCISCO DE LA ALHAMBRA (franciscanos):

- Catedral: (1598) capítulo general, (1688).

64. En uno de ellos, aparecen por primera vez recitado y «ariettas». Entre los villancicos compuestos por Alonso de Blas y Sandoval, o más probablemente por Manuel Ferrerira, para las Navidades de 1707, encontramos dos de ellos con recitados y arietas. El segundo de éstos, «al estilo italiano», incluye una estrofa italiana. C-38-37 (6-11), Biblioteca General de la Universidad de Granada.

65. Actuó la totalidad de la capilla de música de la catedral, incluidos los ministriles: «al Ofertorio, al manifestar el cuerpo y sangre de Nuestro Redentor, y al consumir, cantó la música marauillosas chançonetas, por ser el maestro de los que con más primor hazen esto. Sustituyeron sus pausas los ministriles, sin excesso de los músicos (con ser tan buenos)...». FERriol y CAyCEDo, Alonso de: Libro de las fiestas... Inmaculada Concepcion, Granada, 1616. 
CONVENTO DE SAN GREGORIO EL BÉTICO (clérigos observantes):

- Catedral: (1769) Beatificación de Francisco Caraciolo. Misa y vísperas (varios días).

CONVENTO DE SAN JUAN DE LA PENITENCIA (capuchinos):

- Catedral: (1747) Diferentes patrocinadores institucionales y privados cada día. San Fidel de Sigmaringa y San José de Leonisa (14 días).

- Capilla Real: (1747) El 19 de abril el patrocinador de la fiesta anterior fue la Capilla Real. 3 villancicos. Música de Juan Martínez (textos).

CONVENTO DE SAN JOSÉ (carmelitas descalzas):

- Capilla Real: (1744) Miserere.

CONVENTO DE SANTA CRUZ LA REAL (dominicos):

- Catedral: (1602) Procesión de S. Raimundo, (1640) Gremio de mercaderes de paño. Desgravio a Nuestra Señora. Misa mayor, procesión, (1664) Tribunal del Santo Oficio. Beatificación del martir Pedro de Arbués. Procesión, misa (4 villancicos ${ }^{66}$ ) y vísperas (villancicos). Asistió la capilla de música con su maestro y los racioneros cantores, (1668) música compuesta para la ocasión (8 días), (1797) Cofradía del Dulce Nombre de Jesús. Misa y procesión con salve y letanía.

- Capilla Real: (al menos, 1619-1629) Universidad. Festividad de Santo Tomás de Aquino. Vísperas y misa. Cantores y 4 ministriles.

- Sin especificar capilla: (1671) Tribunal del Santo Oficio. Beatificación del rey Fernando III. La música se dispuso en dos coros paralelos en el centro de la iglesia. Vísperas y misa. 4 villancicos (textos).

CONVENTO DE SANTA INÉS (franciscanas):

- Catedral: (1722) Misa y procesión.

CONVENTO DE SANTA ISABEL LA REAL (franciscanas):

- Sin especificar capilla: (1667) Profesión de la religiosa Isabel Enríquez de la Cueva y Mendoza. 3 villancicos (textos).

CONVENTO DEL ÁNGEL CUSTODIO (franciscanas descalzas recoletas de Santa Clara):

- Catedral: (1702) Entierro de la abadesa Sor Beatriz María de Jesús ${ }^{67}$, (1722), (1736) Entierro del arcediano de la catedral (1752), (1761) Festividad de Santa María Magdalena y festividad de la proclamación del Patronazgo de la Inmaculada ${ }^{68}$. Vísperas y misa (2 días).

66. Se conservan los textos y se señala su ubicación litúrgica: el primero antes de empezar la misa, el segundo después de la Epístola, el tercero en el Ofertorio y el cuarto en la Elevación del Santísimo Sacramento. Posiblemente, el autor de la música fuera Luis Garay, maestro de capilla de la catedral. A-31-130 (25), Biblioteca General de la Universidad de Granada.

67. Tomás de Montalvo, en la descripción del templo, señala que en la parte inferior del coro «sobresale vna tribuna con rexas de bien labrado hierro, y este sitio está destinado para la música, que suele asistir en particulares fiestas». Este mismo autor nos dice: que «después de la muerte [de una religiosa] no cessa el desvelo, pues se da sepultura a los cadáveres con religiosa decencia, asistiendo la capilla de música de la cathedral, que graciosamente haze este obsequio al convento». Montalvo, Tomás de: Vida prodigiosa de la extática virgen y venerable madre Sor Beatriz María de Jesús..., Granada, Imprenta de la Santísima Trinidad, 1719.

68. Entre los comisarios de la fiesta encontramos a dos músicos de la catedral: Carlos Antonio Romero y Gutiérrez (tiple) y Juan Gregorio Ubac y Ferrer (bajonista). Se especifica que tanto en las vísperas como en la misa y otros actos reli- 
- Capilla Real: (1661) Dedicación de su nueva iglesia.

- Colegiata del Salvador: (1718).

ERMITA DE SAN ISIDRO:

- Capilla Real: (1797) Función solemne a Jesús del Paño.

\section{HOSPITAL DEL CORPUS CHRISTI:}

- Catedral: (1614) Cofradías del Santísimo Sacramento y de la Misericordia. Procesión de entierro de ajusticiados.

\section{IGLESIA DE NUESTRA SEÑORA DE LAS ANGUSTIAS:}

- Catedral: (1800) Octavario.

- Capilla Real: (1750) Misa de rogativa con motivo de una sequía. Misa y procesión.

- Colegiata del Salvador: (1636-1644) Misa todos los sábados, festividades de las tres Pascuas y Ascensión.

\section{IGLESIA DE SAN BARTOLOMÉ:}

- Colegiata del Salvador: (1678) Basílicas de San Bartolomé y San Lorenzo. Primeras y segundas vísperas, misa y torre (ministriles), (1695-1697) Basílicas de San Bartolomé y San Lorenzo.

\section{IGLESIA DE SAN CECILIO:}

- Colegiata del Salvador: (1689-1698) Basílica. Vísperas y misa.

\section{IGLESIA DE SAN GIL:}

- Capilla Real: (1742-1743) Hermandad de María Santísima de las tres necesidades ${ }^{69}$. Procesión del Santo Entierro el Viernes Santo (se citan otras capillas musicales acompañantes).

\section{IGLESIA DE SAN ILDEFONSO:}

- Catedral: (1600) Cofradía del Santísimo Sacramento. Fiesta del Santísimo Sacramento. Cantores y ministriles, (1726) Basílica.

- Capilla Real: (1603-1604) Cofradía del Santísimo Sacramento. Fiesta del Santísimo Sacramento. Cantores y ministriles, (al menos 1796) Hermandad de Nuestra Señora de la Pureza. Función anual.

giosos, estuvieron «alternando los sonoros conciertos con las areas y cantadas más especiales y exquisitas de Roma y de las principales cortes de Europa... cerró tan solemnes cultos con el Admirable a todas las vozes y con todo golpe de los instrumentos para ocultar a su Magestad Sacramentada». Leg. 2 y 302, Archivo de la catedral de Granada.

69. Según Jorquera, esta hermandad servía en la Iglesia de Santiago en la primera mitad del siglo XVII. HENRíQUEZ DE Jorquera, F.: Anales de Granada, p. 224. 
IGLESIA DE SAN JUAN DE LOS REYES:

- Capilla Real: (1627) Basílica. Primeras y segundas vísperas, misa y torre (ministriles).

- Colegiata del Salvador: (1628) Basílica. Primeras y segundas vísperas, misa y torre (ministriles), (1684) Basílica.

IGLESIA DE SAN JOSÉ:

- Catedral: (1592-1593) Fiesta de San José. Cantores y ministriles, (1603) Ministriles.

IGLESIA DE SAN JUSTO Y PASTOR:

- Capilla Real: (al menos, 1619-1629 / 1648) Universidad. Festividad de Santa Catalina. Vísperas y Misa. Cantores y 4 ministriles.

\section{IGLESIA DE SAN LUIS:}

- Catedral: (al menos 1796) Hermandad de Nuestra Señora de la Luz. Función anual. Manifiesto, misa cantada, procesión con salve solemne y letanía.

- Capilla Real: (1667-1675) Basílicas de San Luis y Santa Isabel de los Abades.

- Colegiata del Salvador: (1676-1697) Basílicas de San Luis y Santa Isabel de los Abades.

IGLESIA DE SAN MATÍAS:

- Catedral: (1728).

IGLESIA DE SAN MIGUEL:

- Catedral: (1728) 2 actuaciones.

- Capilla Real: (1732) Procesión general de impedidos.

- Colegiata del Salvador: (1677-1683) Basílica. Primeras y segundas vísperas, misa, (1692-1697) Basílica.

- Sin especificar capilla: (Sin fecha. s. XVIII) «Quintillas que se han de cantar... en la novena del Señor San Miguel en su parroquia... cada tarde las suyas» (textos).

\section{IGLESIA DE SAN NICOLÁS:}

- Catedral: (al menos 1577) Universidad. Festividades de Santa Catalina y San Nicolás. Víspera y misa. 5 Ministriles.

- Capilla Real: (al menos 1616-1629 / 1648) Universidad. Festividad de San Nicolás. Vísperas y misa. Cantores y 4 ministriles.

\section{IGLESIA DE SAN PEDRO Y SAN PABLO:}

- Capilla Real: (1746), (al menos 1796) Hermandad de Nuestra Señora de las Buenas Dichas. Memoria anual de la aparición de la imagen.

- Colegiata del Salvador: (1764) Pasión Jueves Santo («cantar los pasillos que ocurran en medio del sermón»). 
IGLESIA DE SAN SALVADOR:

- Colegiata del Salvador: (1776), (1778).

\section{IGLESIA DE SANTIAGO:}

- Catedral: (1640) Procesión $n^{70}$, (1703-1704) Basílica, (1706) Basílica.

- Capilla Real: (1640) Procesión, (1700-1701) Basílica.

- Colegiata del Salvador: (1640) Procesión.

\section{IGLESIA DE SANTA ANA:}

- Catedral: (1611-1616) Basílica. Primeras y segundas vísperas, misa y torre. Cantores y ministriles, (1692) Basílica.

- Capilla Real: (1607-1610) Basílica. Primeras y segundas vísperas, misa y torre. Cantores y ministriles, (1617-1626) Basílica, (1649) Basílica, (1664) Basílica, (1666-1677) Basílica.

- Colegiata del Salvador: (1627- al menos 1629) Basílica. Primeras y segundas vísperas, misa y torre. Cantores y ministriles, (1636) Domingo de Ramos, Miércoles Santo y Viernes Santo, (1658-1663) Basílica, (1665) Basílica, (1678-1684) Basílica.

\section{IGLESIA DE SANTA ESCOLÁSTICA:}

- Capilla Real: (1664) Basílica. Primeras y segundas vísperas, misa y torre (ministriles), (16681671) Basílica.

- Capilla del convento de San Antón: (1667) Basílica. Primeras y segundas vísperas, misa y torre (ministriles, contratados aparte).

\section{IGLESIA DE SANTA MARÍA MAGDALENA:}

- Capilla Real: (1722) Cofradía de Nuestra Señora de la Candelaria. Fiesta de la Candelaria. Fiesta y procesión, (1775-1776) Hermandad del Santísimo Cristo de la Esperanza y Vía Sacra. Fiesta principal.

- Colegiata del Salvador: (1730).

\section{IGLESIA DEL SAGRARIO:}

- Catedral: (1640) Hermandad de los estudiantes. Desagravio de Nuestra Señora. Vísperas y misa. A partir de 1702, se decretará que sólo esta capilla sirva aquí.

- Colegiata del Salvador: (al menos 1661).

MONASTERIO DE NUESTRA SEÑORA DEL DESTIERRO (basilios):

- Catedral: (1640) Mercaderes del gremio de la especiería. Desagravios a Nuestra Señora. Misa.

70. De esta iglesia salió una de las múltiples procesiones que se organizaron por los desagravíos de Nuestra Señora, en 1640, «y sin ir religiones en ella, no faltaron en tanto autorizado bonete, capillas, pues fueron las tres de música que esta ciudad tiene». Paracuellos, Luis de: Elogios a María Santísima..., Granada, 1651. 
MONASTERIO DE SAN JERÓNIMO (jerónimos):

- Catedral: (1543) Misa, (1726) Entierro. 1 cantor y un ministril (como refuerzo de la capilla de San Jerónimo).

- Capilla Real: (1758) El 11 de agosto piden dos primeros violines y un bajón como refuerzo a su capilla para la celebración de la festividad de la Asunción (debía ser la costumbre).

MONASTERIO DE SANTA PAULA (jerónimas)

- Catedral: (1543) Toma de velo, (1722) Entierro.

ORATORIO DE SAN FELIPE NERI:

- Catedral: (1673), (1693)

\section{APÉNDICE N 2: SALIDAS DE LAS CAPILLAS MUSICALES FUERA DE LA CIUDAD}

\section{ALBOLOTE:}

- Capilla Real: (1656), (1681), (1682).

\section{ALCALÁ LA REAL:}

- Catedral: (al menos 1566) Cabildo de la ciudad. Muy frecuentes los desplazamientos a esta población, sobre todo de ministriles.

\section{ALFACAR:}

- Catedral: (1621) 2 ministriles, (1717), (1719) 5 músicos, (1727) 3 cantores, 2 seises y 2 ministriles.

- Colegiata del Salvador: (1737).

\section{ALGARINEJO:}

- Catedral: (1769) Conde de Luque. 4 músicos.

- Colegiata del Salvador: (1786).

\section{ALHAMA:}

- Capilla Real: (1600-1602/ 1605) Fiestas del Santísimo Sacramento. Ministriles (40 ducados), (1687).

\section{ALHENDÍN:}

- Capilla Real: (1757).

\section{ALMUÑÉCAR:}

- Catedral: (1774) Traslación del Santísimo Sacramento a la nueva parroquia. 7 músicos (16 días).

- Capilla Real: (1598) Ministriles, (1647). 


\section{CHURRIANA:}

- Catedral: (1722) 3 músicos y 2 seises, (1723).

- Capilla Real: (1653).

\section{COGOLLOS:}

- Colegiata del Salvador: (1783).

DÍLAR:

- Colegiata del Salvador: (1719), (1779).

\section{FUENTE VAQUEROS:}

- Colegiata del Salvador: (1795).

\section{GAVIAS:}

- Catedral: (1614), (1731) Maestro de capilla, cantores y ministriles.

GÓJAR:

- Catedral: (1687) 4 músicos.

GÜEJAR:

- Capilla Real: (1681).

\section{HUELMA:}

- Capilla Real: (1715).

HUÉTOR:

- Capilla Real: (1681).

ÍLLORA:

- Catedral: (1615) cantores, (1631) 3 cantores y 3 ministriles.

- Capilla Real: (1670), (1680), (1703) Corpus. 8 músicos, (1746).

- Colegiata del Salvador: (1743), (1773-1774) Corpus y octava, (1777), (1779-82), (1784), (1786), (1795).

\section{IZNALLOZ:}

- Catedral: (1625) 3 cantores, 3 ministriles, (1634) 5 cantores, (1645) 2 cantores (4 días), (1693) 3 músicos, (1697) 4 músicos, (1720-1721) 3 músicos, (1723-1725).

- Capilla Real: (1653) en dos ocasiones.

- Colegiata del Salvador: (1789).

\section{LÁCHAR:}

- Capilla Real: (1657). 
LOJA:

- Catedral: (1628) maestro de capilla, cantores, 2 seises, 3 ministriles.

MOCLÍN:

- Catedral: (1730).

MONTEJÍCAR:

- Catedral: (1634) 2 cantores.

- Capilla Real: (1665).

MONTEFRÍO:

- Capilla Real: (1685).

- Colegiata del Salvador: (1773-1774), (1776-1777), (1779-1783) Corpus y Ascensión, (17851786), (1800).

MOTRIL:

- Capilla Real: (al menos 1599-1604) Se especifica «como en cada vn año». Fiestas del Santísimo Sacramento. Cantores y ministriles, (1692) Corpus, (1707) Corpus y octava (13 días), (1709) Corpus, (1722) Corpus, (1724) Corpus.

- Colegiata del Salvador: (1738-1739) Corpus y octava, (1742), (1748) Celebración de la institución de esta iglesia como colegiata, (1756), (1789).

\section{NIGÜELAS:}

- Catedral: (1737) 2 tenores, 1 contrato, 2 seises, 2 ministriles.

NÍVAR:

- Colegiata del Salvador: (1750).

OGÍJARES:

- Catedral: (1724-1725), (1731).

OTURA:

- Catedral: (1639) 3 cantores (4 días), (1708) Fiesta de San Blas. 4 músicos, (1720) 4 músicos.

- Capilla Real: (1682) 2 cantores, 2 seises, 2 ministriles.

\section{PADUL:}

- Colegiata del Salvador: (1743).

\section{PRIEGO:}

- Capilla Real: (1703) Corpus. 8 músicos. 
RUTE:

- Colegiata del Salvador: (1740).

SALOBREÑA:

- Capilla Real: (1642), (1663).

SANTA FE:

- Catedral: (1602) Honras de Luis I. 2 cantores y ayudante de organista, (1617) cantores y ministriles, (1706) 4 músicos, (1735) 3 cantores, 2 seises, 2 ministriles, (1746) Honras de Felipe V. 12 músicos, (1721) 3 músicos, (1725) 1 músico.

- Capilla Real: (1599) Fiestas del Santísimo Sacramento. 4 cantores, (1714), (1724).

TORRE-CARDELA:

- Catedral: (1668) Fiesta patrocinada por Diego Girón. Contralto, tenor, arpista y bajonista.

\section{UTRERA:}

- Catedral: (1725) 2 músicos.

VÁLOR:

- Catedral: (1752) Fiesta celebrada por la Marquesa de Pesas. 6 músicos. 


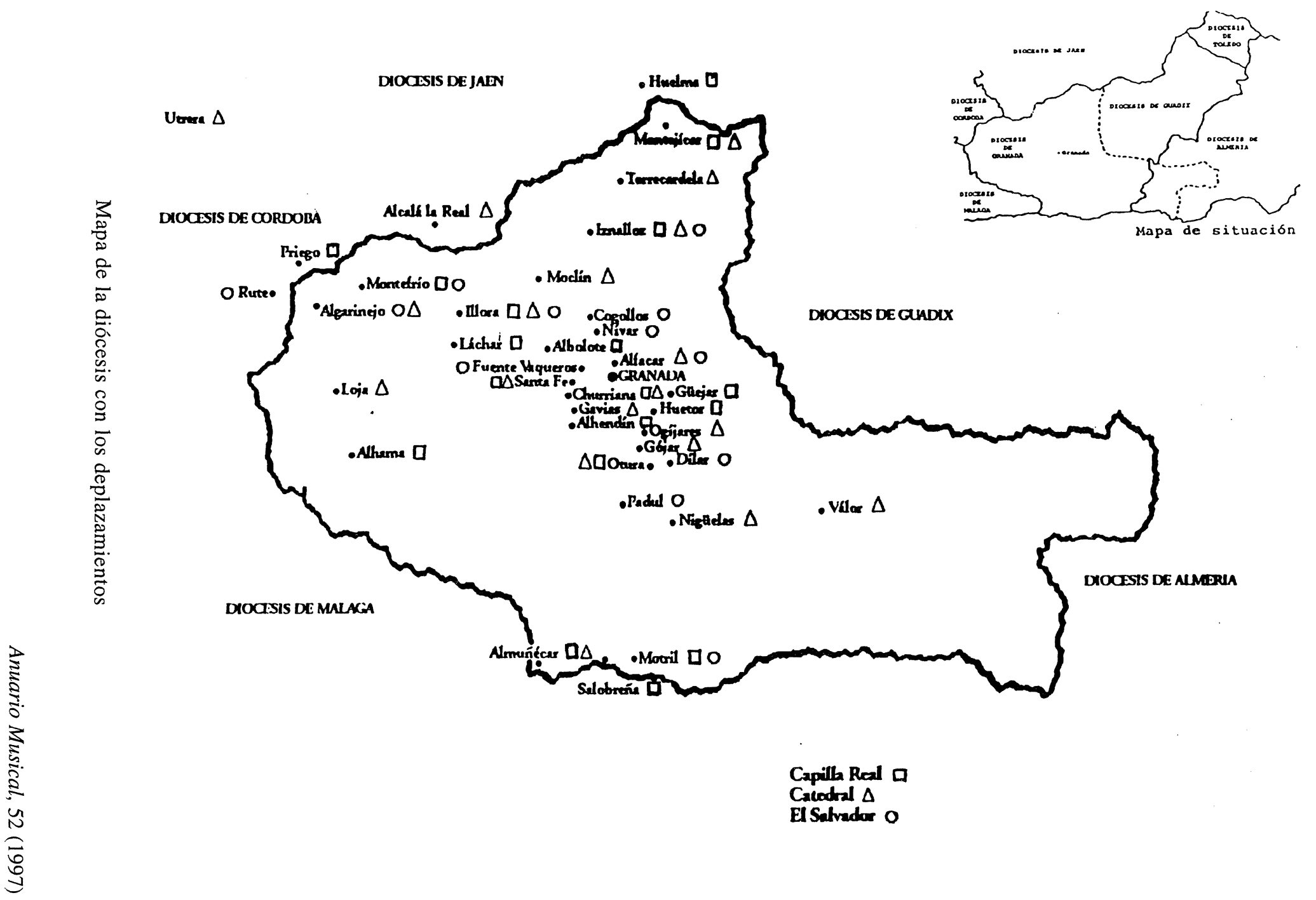




\section{APÉNDICE No 3: TIPOLOGÍA DE PLAZAS ${ }^{71}$}

\section{CATEDRAL}

Racioneros: Sus rentas, de la Mesa capitular, equivalían a 3/4 de una canonjía.

- Cantores: 4, una para cada registro vocal. Creadas en 1539.

- Organista: Creada en 1619.

- Maestro de capilla: Creada en 1638.

Asalariados: Sus rentas proceden de la Fábrica.

- Sochantres.

- Segundos sochantres, salmistas, versicularios: número variable.

- Segundo organista.

- Cantores: número variable.

- Ministriles/instrumentistas: número variable.

- Seises: número variable.

- Afinador de los órganos: No permanente. Cargo asociado al organista.

\section{CAPILLA REAL}

Capellanías reales: Prebenda equivalente a los capellanes de merced.

- Cantores: 4, una para cada registro vocal. Creadas en 1526.

- Organista: Creada en 1526.

- Maestro de capilla: Creada en 1550.

\section{Asalariados}

- Medios capellanes («amovibles»= no perpetuos): 4 cantores.

- Cuartos capellanes ( «amovibles»= no perpetuos): 6 cantores.

- Sochantre.

- Segundo sochantre, salmistas, versicularios: número variable.

- Cantores: número variable.

- Ministriles/instrumentistas: número variable.

- Seises: número variable

- Afinador de los órganos: No permanente. Cargo asociado al organista.

71. Creemos necesario hacer algunas aclaraciones a la tabla $\mathrm{n}^{\circ} 1$. Con respecto a las raciones dedicadas a los cantores de la catedral, éstas, ocasionalmente, eran ocupadas por registros vocales diferentes a los de su primitiva asignación. Con anterioridad a las fechas señaladas, eran plazas asalariadas y sus rentas procedían de la Fábrica. En el siglo xviII, las raciones sufrirán diferentes reducciones por trasformación en tres cuartos o medias raciones, según los casos. Las capellanías reales, concedidas a los músicos de la Capilla Real, se suprimirán en 1670, pasando a la categoría de asalariados. Existían diferentes tipos de capellanías. Esporádicamente, algunas de las medias y cuartas capellanías se dedican a oficios no relacionados con la música (maestro de ceremonias, maestro de gramática). Por último, señalar que no siempre se encontraban cubiertas todas las plazas. 


\section{COLEGIATA DEL SALVADOR}

\section{Asalariados}

- Maestro de capilla

- Organista

- Segundo organista: No permanente

- Sochantre

- Segundos sochantres, salmistas, versicularios: número variable.

- Cantores: número variable.

Ministriles/instrumentistas: número variable.

Seises: número variable

Afinador de los órganos: No permanente (s. XVIII). Cargo asociado al organista.

\section{APÉNDICE $n^{\circ} 4^{72}$ :}

\section{VALOR CORRESPONDIENTE A UNA PARTE EN FIESTAS}

\section{CAPILLA REAL}

1630:

Más de 100 ducados

1734:

100 ducados

1778:

100 ducados

\section{CATEDRAL}

1660: $\quad 90$ ducados

1715: 100 ducados

1795: $\quad 120$ ducados

\section{APÉNDICE No 5:}

\section{NÚMERO DE INTEGRANTES DE LA CAPILLA DE MÚSICA DEL SALVADOR (S. XVIII) ${ }^{73}$}

La capilla contaba con 12 plazas asalariadas (incluían maestro de capilla pero no sochantre, organista ni seises).
1748:
13 músicos
1763:
18 músicos
1765-1770:
17 músicos
1783:
21 músicos

72. AC.CR., t. 4, fol. 59; t. 14, fol. 249v; t. 21, 1 cuadernillo, fol. 195r. AC.C., t. 15, fol. 640r; t. 22, fol. 322v. Leg. 328, pieza 4; Libro 41, Archivo de la catedral de Granada.

73. Las siguientes plantillas están extraídas de nuestra tesis doctoral donde se recogen distintos ejemplos de la evolución cualitativa y cuantitativa de las tres capillas musicales estables de la ciudad. Ruiz Jiménez, J.: La colegiata del Salvador..., p. 322-338. 
NÚMERO DE INTEGRANTES DE LA CAPILLA DE MÚSICA DE LA CAPILLA REAL (1758)

La capilla contaba con 20 plazas asalariadas:

1 maestro de capilla

1 organista (tocaba en estas fechas el clave y el violón)

4 tiples

3 contraltos

3 tenores

2 bajos (sochantres)

6 instrumentistas (de ellos 1 arpista y 2 bajones)

Plazas no asalariadas:

1 tenor (parte entera en fiestas)

2 instrumentistas (parte entera en fiestas)

1 intrumentista (media parte en fiestas, acólito menor)

1 ejercitante de violín (acólito mayor)

Posibilidades instrumentales de la capilla:

9 violines

6 oboes

1 corneta

2 chirimías

1 bajoncillo

2 flautas dulces

1 flauta travesera

1 clarín

1 trompa

4 violones

3 bajones

1 clave 